\title{
An Overview of Per- and Polyfluoroalkyl Substances (PFAS) in the Environment: Source, Fate, Risk and Regulations
}

\author{
Ziyad Abunada ${ }^{1}$, Motasem Y. D. Alazaiza ${ }^{2}$ and Mohammed J. K. Bashir ${ }^{3, *(1)}$ \\ 1 School of Engineering \& Technology, Central Queensland University, Coastal Marine Ecosystems Research \\ Centre (CMERC), 120 Spencer St., Melbourne, QLD 3000, Australia; z.abunada@cqu.edu.au \\ 2 Department of Civil and Environmental Engineering, College of Engineering, A'Sharqiyah University (ASU), \\ Ibra 400, Oman; my.azaiza@gmail.com \\ 3 Department of Environmental Engineering, Faculty of Engineering and Green Technology (FEGT), \\ Universiti Tunku Abdul Rahman, Kampar 31900, Malaysia \\ * Correspondence: jkbashir@utar.edu.my
}

Received: 3 November 2020; Accepted: 17 December 2020; Published: 21 December 2020

\begin{abstract}
The current article reviews the state of art of the perfluoroalkyl and polyfluoroalkyl substances (PFASs) compounds and provides an overview of PFASs occurrence in the environment, wildlife, and humans. This study reviews the issues concerning PFASs exposure and potential risks generated with a focus on PFAS occurrence and transformation in various media, discusses their physicochemical characterization and treatment technologies, before discussing the potential human exposure routes. The various toxicological impacts to human health are also discussed. The article pays particular attention to the complexity and challenging issue of regulating PFAS compounds due to the arising uncertainty and lack of epidemiological evidence encountered. The variation in PFAS regulatory values across the globe can be easily addressed due to the influence of multiple scientific, technical, and social factors. The varied toxicology and the insufficient definition of PFAS exposure rate are among the main factors contributing to this discrepancy. The lack of proven standard approaches for examining PFAS in surface water, groundwater, wastewater, or solids adds more technical complexity. Although it is agreed that PFASs pose potential health risks in various media, the link between the extent of PFAS exposure and the significance of PFAS risk remain among the evolving research areas. There is a growing need to address the correlation between the frequency and the likelihood of human exposure to PFAS and the possible health risks encountered. Although USEPA (United States Environmental Protection Agency) recommends the $70 \mathrm{ng} / \mathrm{L}$ lifetime health advisory in drinking water for both perfluorooctane sulfonate (PFO) perfluorooctanoic acid (PFOA), which is similar to the Australian regulations, the German Ministry of Health proposed a health-based guidance of maximum of $300 \mathrm{ng} / \mathrm{L}$ for the combination of PFOA and PFOS. Moreover, there are significant discrepancies among the US states where the water guideline levels for the different states ranged from 13 to $1000 \mathrm{ng} \mathrm{L}^{-1}$ for PFOA and/or PFOS. The current review highlighted the significance of the future research required to fill in the knowledge gap in PFAS toxicology and to better understand this through real field data and long-term monitoring programs.
\end{abstract}

Keywords: poly-fluoroalkyl substances (PFASs); toxicology; PFAS health risk; regulatory values

\section{Introduction}

Widespread surface and groundwater contamination with perfluoroalkyl and polyfluoroalkyl substances (PFASs) has become of great concern in the last few years. PFAS was first realized in the globe through the identification of perfluorooctane sulfonic acid, $\mathrm{C}_{8} \mathrm{~F}_{17} \mathrm{SO}_{3} \mathrm{H}$ (PFOS), in wildlife [1,2]. 
PFASs have recently received increasing global attention because of their persistence and toxicity in the environment, bioaccumulation potential, and possible adverse health impacts [3]. PFAS are commonly have an aliphatic carbon composition in which hydrogen molecules have been replaced by fluorine completely (prefix: per-) or partially (prefix: poly-) [4]. These compounds are characterized by their highly polar and strong carbon fluorine bonds [5]. They are considered as highly fluorinated surfactants that have been applied in numerous industrial applications and manufactured goods including food packaging, firefighting foams, clothes and protective coatings for fabrics and carpets, electronics and fluoropolymer manufacturing [1,2,5-9]. The most extensively produced and frequently detected PFASs in the environments are perfluorooctanoic acid, $\mathrm{C}_{7} \mathrm{~F}_{15} \mathrm{COOH}$ (PFOA) and perfluorooctane sulfonic acid, C8F17SO3H (PFOS) [1]. PFASs have been discovered in different environmental compartments, including water, sediment organisms, and air [6,10-12].

PFAS has been a serious concern to industry, governments scientists, and even to the public worldwide [13]. It has been detected in various aquatic matrixes, including rain, snow, groundwater, tap water, lakes, and rivers with the C8-based substances PFOS and PFOA typically being the dominating compounds $[4,9,14]$. PFAS degradation products can be freely mobile in water, soil, and air, and can be extremely resistant to breakdown by different processes. The complexity of measuring PFAS in various media, and the associated unknown risks are among the challenges facing the current regulatory bodies [4]. Typical concentrations of PFASs in water are very low, however, higher concentrations of $(\mathrm{mg} / \mathrm{L})$ have been observed in surface and groundwater after firefighting activities closed to fluorochemical manufacturing facilities. PFASs spread worldwide has triggered the governmental concern towards regulating the exposure and spread of PFASs [15,16]. Although there is enough evidence about the negative impacts of PFAS on human and animal health, the scale of the risk imposed by PFAS compounds is not fully understood. The current regulations tend to address the potential risk limit for various wildlife where the PFASs persistence, bioaccumulation potential, and toxicity (PBT) raise a great concern [6]. Several studies have reviewed various aspects related to PFASs fate and behavior in different environments. They also reviewed the sources and occurrence of PFOA in drinking water, toxicokinetic, and health impacts [17-21]. Other reviews on PFASs have discussed different aspects such as environmental biodegradation of PFASs, PFASs removal from drinking water treatment plants, wastewater treatment plants and PFASs transformation in landfills [22-24]. The authors are aware of the developing research concerning PFAS and the many reviews investigating the PFAS human exposure, fate, transport, accumulation, health hazard and guidelines [2,5,16,25-31]. The current mini review investigates the PFAS occurrence in collective all geo-environmental compartments and is the first to collate the various international PFAS standards in one article. The current study reviews existing publications in the field of PFAS and aims to: (i) summarize the recent publication in the field of PFAS and ensure easy access of the research on the occurrence and behavior of PFASs in various environments, (ii) to identify knowledge gaps in the PFAS field, particularly the discrepancies in the current prevailing legislation and practices across various countries, and (iii) to present the key future research directions to better address the PFAS issue.

\section{The Developing Trend in PFAS Research}

PFAS was first detected in the early 1950s in the form of PFAO and PFOS as a part of the Teflon production process [4]. A few decades later, in the early 1990s, and due to the development of the analytical techniques and instrumentation advancement, PFAS was detected in environment at low concentrations. The investigation on PFASs was evolved in early 2000s when a voluntary phase- out in production of the parent chemical to PFOS was undertaken [32]. Due to the significant development of PFAS production in 2009, more attention was paid to limiting PFAS production whereby many researchers and institutions investigated the source, fate, and impact of PFAS compounds (Figure 1). The related articles published recently were extracted from Scopus based on the following keywords: perfluoroalkyl and polyfluoroalkyl substances, assessment of perfluoroalkyl substances, accumilation 
toxicity of PFASs, treatment of perfluoroalkyl and polyfluoroalkyl. In total, 122 articles were selected based on their relevancy, scope, and depth of discussion.

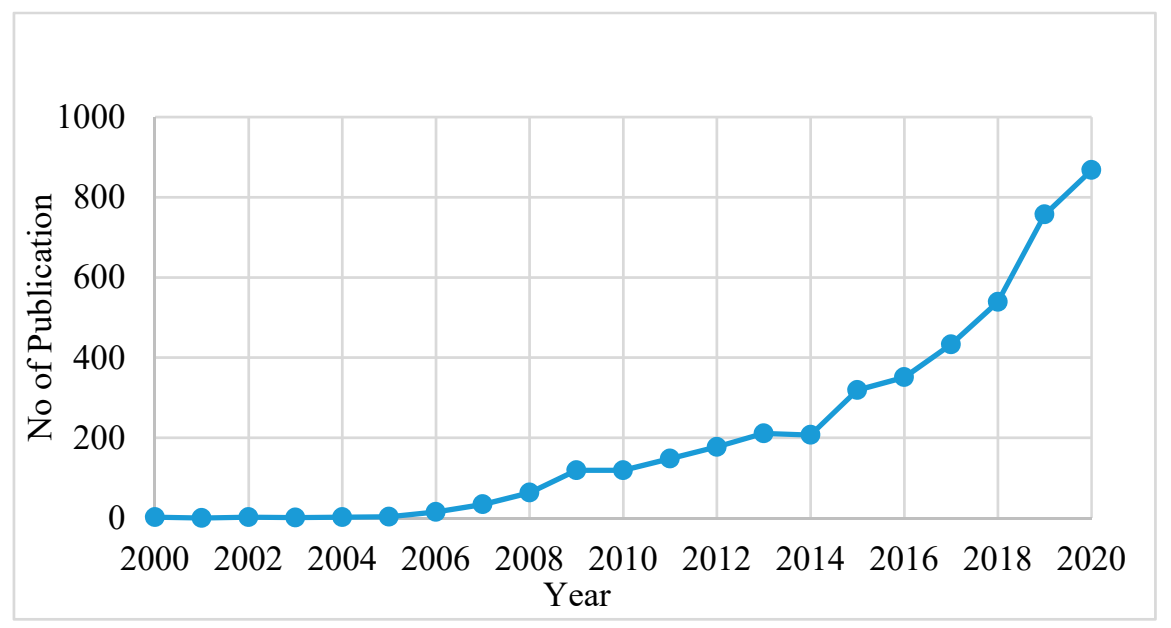

Figure 1. Total number of documents published, concerning PFAS from 2000 to 2020 (data extracted from Scopus; October 2020).

As a result, the research trend reflected by the number of publications concerning perfluoroalkyl and polyfluoroalkyl compounds have been augmented considerably in the last two decades and resulted in a much better understanding of the adverse health effects related to the exposure of PFOA and PFOS [33].

Moreover, it was observed that developed countries have invested much more than other countries on PFAS research, which was reflected by the research funding number of publications as shown in Figure 2. Nevertheless, not all countries share the same concerns and interests due to many various reasons. Some of these reasons are driven by economic factors, where the PFAS is still not on the priority list, as shown in Figure 2. Other factors are associated with industrial and sociopolitical factors, where PFAS form a significant part in industry.

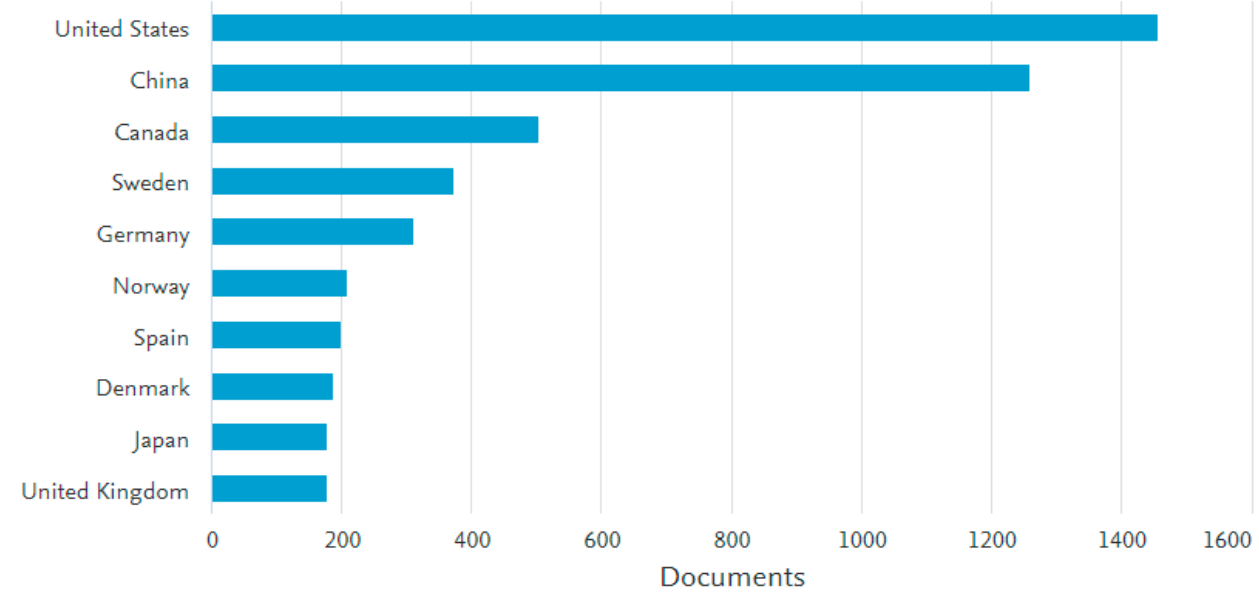

Figure 2. Total number of documents published by top 10 countries concerning PFAS from 2000 to 2020 (data extracted from Scopus; October 2020).

\section{PFASs Occurrence and Transformation}

Due to the strong C-F bonds in PFASs, they are highly stable and PFASs are unlikely to degrade easily in the environmental matrices [34]. PFASs in the environment has been resulted from several sources. The sources of PFASs in groundwater, drinking water, and surface water could be categorized 
into (i) point as well as (ii) diffuse sources. Wastewater treatment plants are considered as the most common point sources of PFASs to surface water. Other forms of point sources have been found to have a high impact on surface water in the USA including industrial pollution from PFAS production sites. In addition, it was observed that high concentrations of PFASs can be existed in surface water closed to commercials and military places due to the usage of aqueous film forming foams (AFFF) that contains PFASs. Landfills are considered as important point sources for PFASs in groundwater that comprise PFAS polluted waste in China, and that they could cause a hazard for tap water pollution [35]. Also, in Europe, landfills have not been supported to a significant degree in terms of their capacity for groundwater PFAS contamination. The following subsections illustrate the different occurrence of PFASs in the environments.

\subsection{PFAS in Environment}

\subsubsection{PFASs in Water}

The level of PFAS as well as their fate in water bodies have been investigated be many researchers as water represents one of the main pathways for human exposure to [36-41]. The consistent detection of PFAS compounds such as perfluoroalkane sulfonates (PFSAs) and perfluoroalkyl carboxylates (PFCAs) in tap water samples at various locations has raised the concern over their potential health risk [37]. Such detection has been reported in drinking water samples in Europe, China, Malaysia, Thailand, USA, Singapore, Vietnam, and Brazil [4,14,20,36,37,40-48]. Other compounds, including perfluoro hexanoic acid (PFHxA) [38], perfluorooctanesulfonamide (PFOSA) [32], and perfluorinated phosphonic acids (PFPAs) [49], are also among the commonly detected compounds in water samples. This relatively persistent level of PFAS exposure increases with the increased drinking water contamination events where it was estimated that the average human daily PFAS intake ranges from 0.17 to $0.21 \mathrm{ng} / \mathrm{kg}$ bodyweight/day for PFOS and PFOA, respectively [50]. The results by Gellrich et al. [50] revealed that short chain PFAS ( $<8$ carbon atoms) were dominant in samples collected from tap water with a maximum level of $42.7 \mathrm{ng} / \mathrm{L}$ followed by mineral water and spring water [50]. One of the kay aspects on PFAS level in drinking water is the difference in PFAS level in both treated and source water. An interesting finding by Lu et al. [37] indicated that PFAS concentration was higher in treated water compared with the source water which could be accounted by the potential contamination that may occur whilst treated water moving through the water network and the treatment plant facilities [37]. Moreover, literature showed that various and inconsistent pattern of PFAS compounds was found on many occasions. While PFOA was dominant PFAS compound in tap water samples tested from Shanghai, Beijing, and Nanjing, PFOS was the key PFAS compound in water samples collected from Shenzhen and Hong Kong, accounting for more than $50 \%$ of the total PFAS compounds.

Moreover, researchers found mysterious temporal and spatial patterns of PFAO and PFOS across the various events where a comparison of PFAS levels in tap water in various Chinese cities revealed that the PFAS level varied significantly from one city to another with the highest was reported in Shanghai [37]. Moreover, the inconsistent and varied PFAS level was also significant across various countries. Quinete et al. [42] found that, unlike the pattern and the level of PFAO and PFAS level in the USA and Japan tap water samples, PFOS level was higher than PFOA in tap water samples collected in China [42]. An average level of total PFCs of $130 \mathrm{ng} / \mathrm{L}$ was measured in tap water samples from Shanghai (China), and a much lower maximum PFCs level was identified in water samples from Toyama (Japan) $(0.62 \mathrm{ng} / \mathrm{L})$ [44]. An average of $2000 \mathrm{ng} / \mathrm{L}$ was identified in in treated drinking water distribution system at the city of Oakdale, USA. This seems to be a very extreme level of PFAS where a health-based drinking water level of $0.04 \mathrm{~g} / \mathrm{L}$ was assessed as a protective lifetime exposure through risk assessment exposure [12].

One of the main concerns about PFAS contamination is their persistence and bioaccumulation properties as well as the potential to travel with either water streams or sediments. Traditional treatment facilities seem unable to eliminate PFASs during normal treatment processes [51]. PFAS discharge 
into water bodies was also reported by Boiteux et al. [47] where river water proved to be impacted by the nearby fluorochemical manufacturing industry. This confirms that discharge of PFOA and PFOS are still detected in nearby industrial and manufacturing facilities. Results showed that river water and sediment samples as well as treated water samples at various stages from the main treatment plant have all showed various level of PFCA compounds coming from the manufacturing industry. Interestingly, PFCA was also detected at sediment samples at $62 \mathrm{~km}$ away from the source in almost $50 \%$ of the samples [47]

The occurrence of PFASs in surface water is frequently happening across many countries around the world [52]. Researchers have conducted several field studies for different types of surface water to investigate the occurrence and presence of PFASs [2,23,29,53,54]. A previous study was conducted to assess the level of PFASs from different locations in Gangs River, India. Results showed that around 15 types of PFASs were found in the water samples where the highest level detected was for PFHxA and PFBS. In addition, significant relationships were detected $(p<0.05)$ between the different PFASs substances such as PFCAs, PFSAs, PFBA, and PFHxS, indicating chemical binding and co-transport with dissolved oxygen carbon (DOC) in fresh and seawater. Consequently, assessed the pollutants concentration and spatial distribution of PFASs in Shuangtaizi Estuary, China. Results showed that the Shuangtaizi Estuary was in general polluted by PFASs. The total concentration of PFASs varied from 66.2 to $185 \mathrm{ng} / \mathrm{L}$ and from 44.8 to $209 \mathrm{ng} / \mathrm{L}$ in surface and bottom water of the Shuangtaizi Estuary, respectively, where the maximum concentration was reported for PFBS and PFBA. The level of PFASs in different environmental matrices was tested including surface runoff water rain, snow, and lake water in an urban area, to identify the sources of PFASs to urban water bodies $[36,39,40]$. Another research conducted by Yin et al. [55] discovered a significant temporal variation of PFASs compounds level over 12 months period due to the seasonal and climatic dry and wet conditions. Moroer, PFASs concentration was a function of the chain length where the level of short-chain compounds including PFBS, PFHxA and PFHpA tend to be highly influenced and decreased by the wet conditions. On contrary the level of long-chain PFASs compounds was more stable in both wet and dry conditions. These findings provide a good understanding to the leachate of PFAS compounds from point source pollution as landfills and treatment plant. The leaching of long chain is more likely controlled by the partitioning effect whilst the short chain leaching is influenced by the climatic conditions [55].

Another main finding in the field of PFAS in water is the variation of the PFAS where PFOA was the major compound with an average concentration of 35\% of the total PFASs levels, in all environmental matrices investigated. In addition, the concentrations, and relative substances of PFASs in surface water were comparable to the concentrations found for urban lakes. Surface water leads to PFOA pollution in urban lakes. A sampling campaign was conducted in different seas in China in 2012. The results revealed that the higher concentration of PFAS was detected in the South Yellow Sea, where FTOH was the predominant substance, contributing 92-95\% of the total PFAS [2].

\subsubsection{PFASs in Soil}

PFAS was detected in soil at various concentrations due to the reach out from various pollutions sources where PFAS compounds retain in soil due to sorption, partition and other complex reaction [56]. Table 1 shows the range of PFAS concentration in soil. The application and the reuse of sludge from wastewater treatment plants in farmlands is one of the main sources that contribute to soil contamination [57]. Other sources could be due to the degradation of fluorotelomer-based materials that lead to the release of PFCAs [43], precipitation, and water irrigation [58]. PFAS compound in soil in coastal areas can be emitted from direct sources which could level the PFAS concentration up to around 8-50 $\mathrm{gg} \mathrm{kg}^{-1}$ soil as was reported in Chinese soil [45] which is somehow higher than the proposed PFCs in soil proposed by the USEPA ( $6 \mathrm{mg} / \mathrm{kg}$ for PFOS and $16 \mathrm{mg} / \mathrm{kg}$ for PFOA). One main concern about PFAS in soil is the potential PFAS release and carryover by plants as well as the possible PFAS leaching to the underneath soil layers and the groundwater. This carryover of PFOA and PFOS to the plant was evident where the PFAS level in plants was proportionally related to the PFOA/PFOS in 
the soil [59]. PFCs uptake from contaminated soil by crops was reported [60], where samples from rye grass, grain, and potatoes showed high potential of PFCs transfer from soil to crops [60]. This resulted in proposing a preventative PFCs limit of $100 \mathrm{ng} / \mathrm{g}$ dry soil in sludge to be reuse for farming purposes as to limit the potential transfer of PFCs from soil to plants and crops [59]. Moreover, the potential leaching of PFAS from soil through vadose zone is another threat that requires more attention and understanding where insufficient data about in-situ soil remediation and contaminants leaching to the groundwater are available [60]. The development of PFAS compounds in the soil system is complex since PFAS compounds can attain both hydrophilic and hydrophobic characteristics [56]. While the transfer of PFAS from soil to plant roots undergo through diffusion and sorption onto roots, there are still insufficient details about the PFC transfer rates in various crops and vegetables [59]. This result was confirmed [59] where they found the straw and grains of maize plants have the same carboxylic and sulfonic functional groups as in the contaminated soil referring to a direct correlation between soil and crops PFASs contamination.

PFASs toxicity their impact on soil microorganisms is among the other factors that can deteriorate the soil quality. Research found that the PFCs can negatively affect the soil functionality where it may disturb soil enzyme activity as well as change the microbial availability and damage the cellular structure [61-63]. The same result was confirmed by Sun et al. [64] as the soil contaminated with PFASs compounds had less bacterial diversity [64]. PFOA and PFOS are the dominating compounds reported in soil where their concentration ranged from $<1$ to around $13,000 \mathrm{ng} / \mathrm{g}$ in soil [56]. The fate of PFASs in the soil is a function of many parameters including soil $\mathrm{pH}$, soil structure, clay content, organic matter content (OM), PFAS characteristics (long versus short chain), and climatic conditions [61]. OM seems to be the most significant controlling factor determining the PFAS toxicity level where the PFAS toxicity is inversely proportional with the soil OM content $[34,65]$. Additional research on PFAS adsorption and migration from soil to the groundwater and how this can migrate with the groundwater is still a research gap needs more investigation and modelling to account for the various PFAS concentrations in various groundwater conditions [60]. Contaminated soil with PFAS is a challenge since there is no definite remediation strategy to address the in situ PFAS remediation. Although soil stabilization using various reagents such as clay and Portland cement seems to be a promising technique for soil remediation, it does not provide an elimination for PFAS where it does not remove PFAS permanently [60]. Finally, the PFAS uptake by plant poses a direct human risk where the food chain represents a main risk pathway. Therefore, a toxicological risk assessment addressing the maximum allowed levels of 1.5 and $0.15 \mu \mathrm{g} / \mathrm{kg}$ body weight as TDI $\mu \mathrm{g} / \mathrm{kg}$ for PFOS and PFOA, respectively, were identified by the European Food Safety Agency (EFSA) as a function of the respective tolerable daily intakes (TDI) of the compounds $[59,66]$.

PFASs compounds are soluble in water and have the potential to leach down to the groundwater particularly in areas with potential source pollution like landfills and treatment plants. PFASs occurrence and leaching was reported by many researchers around the world [22,55,67-69]. The potential PFAS leaching could be alarming in many cases where PFASs were detected at large depths (15 m) below ground [70]. Yet, the leaching speed and behavior vary from one PFASs to another which depends on the soil binding, retardation and adsorption capacity [56]. The leaching characteristics of PFASs compound is a function of the chain length where short chain is more mobile than long ones. An analysis of the landfill leachate from 27 landfills in Australia was investigated by Gallen et al. [22]. Interesting findings presented in their study showed that the landfill leachate was significantly different from one landfill to another with an average PFASs of $1700 \mathrm{ng} / \mathrm{L}$ and a maximum PFAS level of 25,000 ng/L [22]. In contrast, the reported PFAO range in USA landfills was ranging between $(7280-290,000) \mathrm{ng} / \mathrm{L}$ compared with $214,000 \mathrm{ng} / \mathrm{L}$ in China [36]. Nonetheless, these PFAS concentration are highly likely to vary due to the heterogeneous nature of waste dumped in landfills as well as the varied PFAS content in the generated landfilled materials. Operating landfills receiving municipal waste had much more PFAS level than closed ones and the leachate from landfills with construction and demolished materials seems to leach more PFAS than municipal landfills. Another study investigated the leachate 
from 11 landfills in USA and found that PFAO was detected in all samples [70]. Table 2 presents the level of various PFCS and PFAS compounds in leachate and compare the PFASs in water and solid. It can be seen that PFASs levels vary from one compound to another as a function of chain length and climatic conditions as illustrated in the previous sections. The risk associated from the landfill leachate is the potential volumes leachate generated particularly in wet climates, which contributes to the groundwater contamination. The total leachate volume in the USA was estimated to be around 61 million $\mathrm{m}^{3}$ with around $80 \%$ coming from landfills [70]. Meanwhile, the leachate mass of $\sum \mathrm{PFA}$ in China was estimated by around 3 ton per year with the landfill leachate contribute to around $35 \%$ of this quantity [35]. Interestingly, analysis of leachate from young landfills showed much higher PFAS concentration in many occasions confirming the fact that the complexity and persistence of PFAS compound has been developed in the recent years where more frequent PFAS containing materials are in use $[67,70]$. The uniqueness of the landfills associated with its design capacity, climate, age, engineering, dumbed materials and frequency and other factors made it hard to predict the amount of PFAS leachate in various landfills where ad-hoc studies to be conducted. The results from various areas across the globe showed significant variation of PFAS leachate from one country to another where a maximum was reported in Australia $(25,000 \mathrm{ng} / \mathrm{L})$. This was evident while the leachate was significantly lower in Norway (590 to $757 \mathrm{ng} / \mathrm{L}$ ), Germany ( $<0.37$ to $2509 \mathrm{ng} / \mathrm{L}$ ), and China (146 to $4430 \mathrm{ng} / \mathrm{L}$ ) [35]. In conclusion, although the phasing out of PFAS materials and the ongoing effort to eliminate the PFAS release in the environment, yet there seems to be a need to consider more adaptation strategies dealing with PFAS risk. The increasing evidence of PFAS in newly designed and operated landfills indicates the potential exposure to higher leaching risk with greater PFAS concentrations is leaching to the environment is growing [70]. 
Table 1. Ranges of PFAS concentration in soil.

\begin{tabular}{|c|c|c|c|c|c|c|c|c|c|c|c|c|c|}
\hline \multirow[t]{2}{*}{ Header } & \multicolumn{4}{|c|}{$\begin{array}{c}\text { A. Høisæter, et al. [71] } \\
\text { ng/g } \\
\text { PFASS in Soil at Various Depths }\end{array}$} & \multirow{2}{*}{$\begin{array}{c}\begin{array}{c}\text { Cai et al. [63] } \\
\text { ng/g Dry } \\
\text { Weight in }\end{array} \\
\begin{array}{c}\text { Dry soil in } \\
\text { China }\end{array}\end{array}$} & \multirow{2}{*}{$\begin{array}{c}\begin{array}{c}\text { Chen et al. } \\
\text { [69] } \\
\text { ng/g Dry } \\
\text { Weight }\end{array} \\
\text { Tot.PFC } \\
0.34-65.8\end{array}$} & \multirow[t]{2}{*}{$\begin{array}{c}\text { Cai et al. } \\
\text { [61] } \\
\text { ng/g Dry } \\
\text { Weight } \\
\end{array}$} & \multirow[t]{2}{*}{$\begin{array}{c}\text { Gao et al. [72] } \\
\text { ng/g } \\
\text { Dry Weigh from } 32 \\
\text { Samples } \\
\end{array}$} & \multirow{2}{*}{$\begin{array}{c}\begin{array}{c}\text { Wang et al. [73] } \\
\text { The Mean Values } \\
\text { ng/g Dry Weight }\end{array} \\
\text { PFAS in soil at } \\
\text { varying distances }\end{array}$} & \multirow[t]{2}{*}{$\begin{array}{c}\text { Liu et al. } \\
\text { [74] } \\
\text { ng/g Dry } \\
\text { Weight } \\
\end{array}$} & \multirow[t]{2}{*}{$\begin{array}{c}\text { Chen et al. } \\
\text { [75] } \\
\text { ng/g Dry } \\
\text { Weight }\end{array}$} & \multirow[t]{2}{*}{$\begin{array}{c}\text { Dalahmeh } \\
\text { et al. [76] } \\
\text { ng/g Dry } \\
\text { Weight }\end{array}$} & \multirow[t]{2}{*}{$\begin{array}{l}\text { Armstrong } \\
\text { et al. [77] }\end{array}$} \\
\hline & $0-1.0 \mathrm{~m}$ & $1-2 \mathrm{~m}$ & $2-3 \mathrm{~m}$ & $3-4 \mathrm{~m}$ & & & & & & & & & \\
\hline PFOS & $500-3000$ & $1000-6500$ & $1000-3500$ & $1000-1200$ & 130 & 70.5 & $8.6-10.4$ & 0.06 & 2583 & 87 & $0-2$ & $0.6-3$ & 23 \\
\hline PFOA & NA & NA & NA & NA & NA & 93 & $3.3-47.5$ & 0.32 & 50 & $0.3-8$ & 63 & $0.5-0.9$ & 24 \\
\hline PFHxS & NA & NA & NA & - & NA & 61 & NA & 0.19 & 36 & & 65 & & \\
\hline$\sum$ PFCs & NA & NA & NA & NA & NA & - & NA & - & NA & 99 & NA & 8 & $126-809$ \\
\hline PFHxA & NA & NA & NA & NA & NA & NA & NA & 0.09 & NA & NA & NA & $0.2-0.5$ & 8 \\
\hline PFBS & NA & NA & NA & NA & NA & NA & NA & 0.05 & NA & NA & NA & NA & NA \\
\hline
\end{tabular}

Table 2. Ranges and mean concentration of individual PFCs in landfill leachate.

\begin{tabular}{|c|c|c|c|c|c|c|c|c|c|c|c|c|c|c|c|}
\hline \multirow[t]{2}{*}{ Header } & \multicolumn{2}{|c|}{$\begin{array}{l}\text { Gallen et al. [22] } \\
\text { (ng L-1) }\end{array}$} & \multirow{2}{*}{$\begin{array}{c}\begin{array}{c}\text { Busch et al. } \\
{[68]} \\
\left(\text { ng L }^{-1}\right)\end{array} \\
\begin{array}{c}\text { Compounds in } \\
\text { landfill } \\
\text { leachates }\end{array} \\
\end{array}$} & \multirow{2}{*}{ 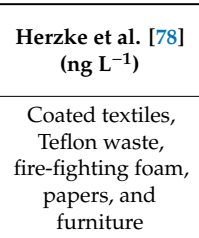 } & \multirow[t]{2}{*}{$\begin{array}{l}\text { Clarke et } \\
\text { al. [79] } \\
\left(\mathrm{ng} \mathrm{L}^{-1}\right) \\
\end{array}$} & \multirow{2}{*}{$\begin{array}{c}\begin{array}{c}\text { Yin et al. } \\
\text { [55] } \\
\text { (ng L-1) }\end{array} \\
\begin{array}{c}\text { Leachate } \\
\text { from CW } \\
\text { outlet system } \\
\text { (Max. level) }\end{array} \\
\end{array}$} & \multirow{2}{*}{$\begin{array}{c}\begin{array}{c}\text { Benskin et } \\
\text { al. [80] } \\
\text { (ng L-1) }\end{array} \\
\begin{array}{c}\text { Municipal } \\
\text { landfill } \\
\text { leachate }\end{array}\end{array}$} & \multirow{2}{*}{$\begin{array}{c}\begin{array}{c}\text { Eggen et al. } \\
{[81]} \\
\left(\text { ng L}^{-1}\right)\end{array} \\
\begin{array}{c}\text { Municipal } \\
\text { land fill } \\
\text { leachates }\end{array}\end{array}$} & \multirow{2}{*}{$\begin{array}{c}\begin{array}{c}\text { Robey et al. [69] } \\
\text { (ng L }\end{array} \\
\begin{array}{c}\text { Foam produced } \\
\text { via the bubble } \\
\text { aeration of } \\
\text { landfill leachate }\end{array}\end{array}$} & \multicolumn{2}{|c|}{$\begin{array}{c}\text { Fuertes et al. } \\
[82]] \\
\left(\mathrm{ng} \mathrm{L}^{-1}\right)\end{array}$} & \multicolumn{2}{|c|}{$\begin{array}{l}\text { Eggen et al. [81] } \\
\left(\text { (ng L L-1) }^{-1}\right)\end{array}$} & \multirow{2}{*}{$\begin{array}{l}\begin{array}{c}\text { Huset et } \\
\text { al. [83] } \\
\left(\text { ng L L }^{-1}\right)\end{array} \\
\begin{array}{l}\text { Leachates } \\
\text { from six } \\
\text { landfill }\end{array}\end{array}$} & \multirow{2}{*}{$\begin{array}{c}\begin{array}{c}\text { Garg et al. [84] } \\
\text { (ng L L }\end{array} \\
\text { Manufacture } \\
\text { and disposal of } \\
\text { electric and } \\
\text { electronic } \\
\text { products }\end{array}$} \\
\hline & $\begin{array}{l}\text { landfill } \\
(>50 \% \\
\text { SW })\end{array}$ & $\begin{array}{l}\text { landfill } \\
(>50 \% \\
\text { C\&D) }\end{array}$ & & & & & & & & $\begin{array}{c}\text { Raw } \\
\text { Leachate in } \\
\text { MSW } \\
\text { landfill }\end{array}$ & $\begin{array}{l}\text { Treated } \\
\text { Leachate in } \\
\text { MSW } \\
\text { landfill }\end{array}$ & $\begin{array}{c}\text { PFCs } \\
\text { analysis- } \\
\text { untreated } \\
\text { leachate } \\
\text { Water } \\
\end{array}$ & $\begin{array}{c}\text { PFCs } \\
\text { analysis } \\
\text {-untreated } \\
\text { leachate } \\
\text { Particles } \\
\end{array}$ & & \\
\hline PFOS & 300 & 1100 & 235 & 570 & 187 & 439 & 4400 & 2920 & 104 & 25 & NA & 2920 & 34 & $56-160$ & 128,670 \\
\hline PFOA & 510 & 1200 & 926 & 9500 & 516 & 3457 & 1500 & 767 & 951 & 590 & 520 & 767 & 4 & $380-1100$ & 118.3 \\
\hline PFHxS & 940 & 3700 & 178 & - & 143 & 308 & 190 & 281 & 2058 & 630 & 870 & 281 & $\mathrm{ND}^{*}$ & $120-700$ & 133,330 \\
\hline PFDS & - & & - & - & $\mathrm{NA}$ & 0.72 & 63 & $<14$ & $\mathrm{ND}$ & & & - & - & $0-16$ & - \\
\hline PFHxA & 1300 & 5000 & 2509 & - & 697 & 868 & 2500 & 757 & 2178 & 65 & 77 & 757 & ND & $270-2200$ & 76 \\
\hline PFHpA & 360 & 760 & 280 & & NA & 486 & 690 & 277 & 454 & - & - & 277 & ND & $100-2800$ & 9 \\
\hline PFNA & 29 & 98 & 80 & - & 62 & 100 & 450 & 539 & 64 & - & - & 539 & ND & 19-140 & 8 \\
\hline PFDA & 22 & 46 & 51 & - & $\mathrm{NA}^{*}$ & 27 & 1100 & 75 & 87 & - & - & 70 & ND & $0.3-64$ & 8 \\
\hline PFAA & $\mathrm{NA}$ & NA & NA & - & - & 55 & - & - & - & - & - & - & - & - & - \\
\hline PFBS & & & 1350 & NA & 112 & 1916 & 190 & - & - & - & - & $<5$ & ND & $280-2300$ & - \\
\hline PFPeA & & & & & & & & & & 11 & 325 & - & - & - & \\
\hline
\end{tabular}

PFDA perfluorodecanoic acid, PFBS nonafluorobutane-1-sulfonic acid, PFHpA perfluoroheptanoic acid, PFHxS perfluorohexane sulfonate, PFNA perfluorononanoic acid. ND*: not detected, NA*: not analysed. 


\section{PFAS Treatment and Clean Up: Challenges and Achievement}

Due to the persistence nature of the PFAS compounds, landfills and sewage treatment plants are highly likely to be a potential point source of PFAS emissions. Although the rapid advancement in PFAS testing and detection, yet the available standard analytical methods still short and there is very little experimental data detailing the physicochemical properties and partitioning constants of PFAS [19]. This place the treatment process of PFAS under the stress of producing precise and consistent outcomes. The literature presents various treatment methods of PFAS in various environment. Immobilization and plasma arc destruction are among the recommended methods to irreversibly transform PFAS waste. Some studies support the utilization of high temperature incineration as well as the usage of plasma destruction of PFAS in waste. It may be possible for certain types of waste. However, in the absence of regulation, there is no specific method to guarantee the universal adoption of such safer methods of disposing of PFOS wastes. In European wastewaters, it was found that PFOA is the most commonly found compound [84]. Conventional processes of wastewater treatment were found to be ineffective in removing of PFOA [85]. Other studies have recorded higher concentrations of PFOA in wastewater effluents than influences, possibly due to the transformation of the compounds of its precursor [21]. It was revealed that the degradation of precursor compound substances is a major supplier to environmental PFAS pollution. Thus, this part focuses on the treatability of PFAS compounds via conventional and modern water treatment processes. A comprehensive revision is judgmentally required to have a clear understanding on the transformation, migration and treatment of these substances in ecosystem and their potential influence on the secondary formation of PFOS and PFOA [86]. In order to eliminate and/or degrade PFAS, different pre-treatment methods have been tested in terms of their efficacy $[19,20]$. Some of these elements can theoretically be implemented as either a post-treatment or pre-treatment method with controlled aquifer recharge as summarized in Table 3.

Table 3. Potential Treatment technologies of PFAS.

\begin{tabular}{cc}
\hline Mechanism & Treatment Process \\
\hline & Advance oxidation processes \\
Electrochemical oxidation & Incinerations \\
Destructive Treatment & Sono-chemical \\
& Biodegradation \\
& Photolysis \\
\hline Non-Destructive treatment & Adsorption \\
& Ion exchange \\
& Fractionation \\
\hline
\end{tabular}

A detailed review summarizing the sorption mechanism along the sorption coefficients and capacity of PFAS on sediments is available [11]. Adsorption via activated carbon and ion exchange resins have been widely employed especially for pump-and-treat remediation to extract PFAS from polluted groundwater [52]. Compared to others, the use of GAC for PFAS removal has been recommended as a cheaper process, and it is the most recognized treatment technology for the groundwater contaminated by PFOS and PFOA [19]. Although the removal efficiency of polyfluoroalkyl substances by granular activated carbon was $>90 \%$, yet the sorption kinetics are normally faster for longer-chained PFAS [87]. For example, Kucharzyk et al. [19] reported that GC, which is optimized and applied effectively for the removal of PFOS, may not be appropriate for the removal of shorter-chained PFAS.

There is a risk that shorted-chained PFASs are more likely than their longer chain counterparts to split through a GAC medium. Otherwise, given the highly persistent existence of PFAS, stockpiling of spent GAC would turn out to be a serious hazardous waste management concern. Storage space is often restricted in MAR systems, and when leaching to groundwater, the disposal of PFAS polluted 
GAC at landfills can present a secondary contamination source to the ecosystem near the landfill site. Methods that can effectively kill PFAS are therefore highly desirable in both polluted water and stockpiled GAC. Other researchers have shown that nanofiltration can successfully extract PFOA from a spiked sample of groundwater [47]. In their study, three different levels of PFOA, including 5, 50, and $100 \mu \mathrm{g} / \mathrm{L}$, were examined, and it was noticed that the remediation effectiveness was higher at a high PFOA level. At higher PFAS level, RO process could contribute to about $99 \%$ removal of PFOS with an initial concentration of 500 to $150,000 \mu \mathrm{g} / \mathrm{L}$ and a combination of nanofiltration TOGOTHER WITH reverse osmosis (RO) can achieve 99\% PFOS removal and 90-99\% PFOA (10,000 $\mu \mathrm{g} / \mathrm{L})$ removal throughout four days of treatment [88]. Nevertheless, the technique was not capable to ensure that the treated effluent was less than the recommended guideline values, even with high removal acacias (99\%). Using RO and nanofiltration membranes showed that accumulation (fouling) of PFAS cause a substantial reduction in flux in the filtration process [88]. Unfortunately, the main drawbacks of nano-filtration processes are the low water recovery (75\% to $80 \%$ ) and the existence of high concentrations of inorganic substances comprising magnesium calcium, and silica in groundwater [89]. This provides an indication on the volume of brine water produced which also needs additional remediation before its final discharge. Table 4 illustrates the performance of numerous selected treatment technologies for PFAS at the laboratory-scale. 
Table 4. Performance of numerous treatment technologies for PFAS (laboratory-scale).

\begin{tabular}{|c|c|c|c|c|}
\hline Process & Treatment Mechanism & Operation Conditions & Performance & References \\
\hline UV-Fenton & Oxidation & $\begin{array}{l}30.0 \mathrm{mM} \text { of } \mathrm{H}_{2} \mathrm{O}_{2}, 2.0 \mathrm{mM} \text { of } \mathrm{Fe}^{2+}, \mathrm{pH} 3.0 . \\
\text { and } 9 \mathrm{~W} \mathrm{UV} \text { lamp }(\max =254 \mathrm{~nm})\end{array}$ & $\begin{array}{c}>95 \% \text { PFOA destruction from } \\
8.2 \mathrm{mg} / \mathrm{L} \text { and defluorination } \\
\text { efficiency of } 53.2 \%\end{array}$ & [88] \\
\hline Oxidation & $\begin{array}{c}30.0 \mathrm{mM} \text { of } \mathrm{H}_{2} \mathrm{O}_{2}, 2.0 \mathrm{mM} \text { of } \mathrm{Fe}^{2+}, \mathrm{pH} 3.0 . \text { and } \\
9 \mathrm{~W} \mathrm{UV} \mathrm{lamp}(\max =254 \mathrm{~nm})\end{array}$ & $\begin{array}{l}\text { PFOA treatment }>95 \% \text { from } 8.2 \mathrm{mg} / \mathrm{L} \text { while } \\
\text { defluorination effectiveness }=53 \%\end{array}$ & $\begin{array}{l}\text { Removal efficiency 100\% (PFOA } \\
559 \mathrm{mg} / \mathrm{L})\end{array}$ & [90] \\
\hline Oxidation & $\begin{array}{l}\text { Light-activated persulfate at } 50 \mathrm{mM} \mathrm{\&} \\
\text { radiation of } 4 \mathrm{~h} \text { of }\end{array}$ & Removal efficiency 100\% (PFOA 559 mg/L) & $\begin{array}{l}73 \% \text { removal efficiency of PFOS } \\
\text { throughout } 120 \mathrm{~min}\end{array}$ & [91] \\
\hline Sonolysis & $\begin{array}{l}\text { PFOS level from } 65 \mu \mathrm{g} / \mathrm{L} \text { to } 13,100 \mu \mathrm{g} / \mathrm{L} \text { ) were } \\
\text { treated through ultrasonic at frequency } 505 \\
\mathrm{kHz} \text { and power density } 187.5 \mathrm{~W} / \mathrm{L})\end{array}$ & $73 \%$ removal of PFOS within $120 \mathrm{~min}$ & $\begin{array}{l}55-98 \% \text { removals for different } \\
\text { analyzed PFASs. Ozonation can } \\
\text { create potentially toxic } \\
\text { transformation products }\end{array}$ & [92] \\
\hline Oxidation & Tested for 18 analyzed PFASs $3 \mathrm{~h}$ of ozonation & $\begin{array}{l}55-98 \% \text { removals for different analyzed } \\
\text { PFASs. Ozonation can create potentially } \\
\text { toxic transformation products which needs to } \\
\text { be investigated in future research. }\end{array}$ & $\begin{array}{l}\text { Adsorption capacity } 41.3 \mathrm{mg} / \mathrm{g} \\
\text { of PFOA and } 72.2 \mathrm{mg} / \mathrm{g} \text { of PFOS }\end{array}$ & [93] \\
\hline Adsorption & $\begin{array}{c}10 \mathrm{mg} / \mathrm{L} \text { of PFOA; surface area: } 534 \mathrm{~m}^{2} / \mathrm{g} \text {; time } \\
\text { of equilibrium } 24 \mathrm{~h} ; \mathrm{pH} 5\end{array}$ & $\begin{array}{l}\text { Adsorption capacity } 41.3 \mathrm{mg} / \mathrm{g} \text { of PFOA and } \\
72.2 \mathrm{mg} / \mathrm{g} \text { of PFOS }\end{array}$ & $\begin{array}{l}\text { Adsorption capacity } 510 \mathrm{mg} / \mathrm{g} \\
\text { of PFOA }\end{array}$ & [94] \\
\hline Adsorption & $\begin{array}{c}700 \mathrm{mg} / \mathrm{L} \text { of PFOA; surface area: } 1539 \mathrm{~m}^{2} / \mathrm{g} ; \\
\text { time of equilibrium } 24 \mathrm{~h} ; \mathrm{pH} 7\end{array}$ & Adsorption capacity $510 \mathrm{mg} / \mathrm{g}$ of PFOA & $\begin{array}{l}\text { Adsorption capacity } 166 \mathrm{mg} / \mathrm{g} \\
\text { of PFHxA }\end{array}$ & [95] \\
\hline Ion exchange using IRA 67 & $\begin{array}{l}\text { Particle size: } 3-1.2 \mathrm{~mm} ; 120 \mathrm{mg} / \mathrm{L} \text { of } \mathrm{PFHxA} ; \\
\text { time of equilibrium } 12.5 \mathrm{~h} \text {; } \mathrm{pH} 4\end{array}$ & Adsorption capacity 166 mg/g of PFHxA & $\begin{array}{l}\text { Adsorption capacity } 2390 \mathrm{mg} / \mathrm{g} \\
\mathrm{mg} / \mathrm{g} \text { of PFOS }\end{array}$ & [96] \\
\hline Ion exchange using IRA 67 & $\begin{array}{l}\text { Particle size: } 3-1.2 \mathrm{~mm} ; 200 \mathrm{mg} / \mathrm{L} \text { of PFOS; } \\
\text { time of equilibrium } 20 \mathrm{~h} \text {; } \mathrm{pH} 3\end{array}$ & Adsorption capacity 2390 mg/g mg/g of PFOS & & \\
\hline
\end{tabular}


In the degradation of PFOA and PFOS at ppm $(\mathrm{mg} / \mathrm{L})$ levels, methods such as advanced oxidation processes (AOPs) using ozone $\left(\mathrm{O}_{3}\right)$ and $\mathrm{H}_{2} \mathrm{O}_{2} / \mathrm{Fe}^{2+}$ were not effective. At $254 \mathrm{~nm}$, direct $\mathrm{UV}$ irradiation was not capable of removing PFOA [84]. At relatively low temperatures (e.g., $40{ }^{\circ} \mathrm{C}$ ), reaction rates were low and activation at higher temperatures was needed to speed up the reaction [19]. A functional and scalable approach for treating PFAS appears to be sonochemical therapy. For the removal of PFASs from water, AOPs based on heterogeneously catalyzed ozonation were used. Various combinations of ozone, a catalyst and persulfate were performed in laboratory-scale ozonation experiments. These combinations showed high removal efficiency, using all three parameters [97]. In the pilot-scale setup, within three hours of treatment, the concentrations of all 18 analyzed PFASs were reduced significantly. Given that the assessed ozonation treatment is already commercially available for large-scale applications today, it could easily be used in current water treatment trains, but ozonation will create potentially harmful conversion products that will need to be explored in future research. It promises to be used to decrease PFAS levels in PFAS-loaded sorbents as a destructive tool (e.g., spent GAC) [98]. Hydroxyls radicals are normally generated within the bubble from the cleavage of $\mathrm{H}_{2} \mathrm{O}$ and $\mathrm{O}_{2}$ to react with or abolish the pollutants. In another study, sonochemical treatment using a pilot-scale high-power sonicator was carried out for the treatment of 2,4,5-trichlorophenoxyacetic acid [99]. It can be concluded the sonochemical treatment process was effective in removing organic compounds $(>90 \%)$ within a very short duration (a few minutes). Although the sonochemical technique appears promising for the large-scale treatment of PFAS contaminated products, incomplete PFAS destruction is currently viewed as a disadvantage. A recent study showed that 6:2 fluorotelomer sulfonate was less susceptible than perfluoroalkyl analogs (PFOA and PFOS) to sonochemical destruction and decreased the defluorination rate with a decreased degree of fluorination [100]. Given the recent focus on integrating deferential PFAS treatment processes in treatment trains in order to optimize the overall efficacy of PFAS destruction [98] In order to optimize the overall destruction of PFAS in the polluted media, it seems important to investigate the potential pairing of sonochemical treatment with alternative methods.

Table 5 summarizes the performance of various type of adsorbents in treating per- and polyfluoroalkyl substances. As a conclusion based on the treatment techniques performance investigated previously and partially summarized in Tables $3-5$, traditional biological processes of wastewater treatments were found ineffective in removing of PFOA [85]. Due to the exceptional chemical futures of PFAS including high solubility, surfactant property, and thermal stability, various traditional and well-established treatment processes, including chemical oxidation, air stripping, and thermal treatment are invective in treating PFAS [19]. Similarly, Page et al. [21] indicated that numerous techniques like adsorption via granular/ powdered activated carbon, ion exchange resins, reverse osmosis, membrane filtration, advance oxidation techniques, and sono-chemical decomposition have been investigated for the treatment of PFOA and PFOS from water and wastewater. Accordingly, among several physical and chemical treatment processes, adsorption process has been comprehensively tested and have shown to be effective methods for eliminating PFASs from water. It can be observed that the adsorption capacity and treatment performance using adsorption process were increased when the surface area increase [19]. Yet, in this adsorption process, the pollutant will be transferred from liquid phase to solid waste which will need to be managed as a hazardous waste. The main concern and limitation of $\mathrm{RO}$ and nanofiltration membranes is the fouling where PFAS cause a substantial reduction in flux in the filtration process [88]. Also, the low water recovery and the existence of high concentrations of inorganic substances comprising magnesium calcium, and silica in groundwater [89]. Yet, the brine water produced also needs additional remediation before its final discharge. Advanced oxidation processes are promising and have high potential in the removal of PFASs from water. AOPs were used recently at laboratory-scale and showed high removal efficiency, using all three parameters [97]. 
Table 5. Summary performance of various type of adsorbents in treating Per- and Polyfluoroalkyl Substances.

\begin{tabular}{|c|c|c|c|c|}
\hline Sorbent & Adsorbate & Operation Conditions & Adsorption Capacity & References \\
\hline Clay minerals (surface area: $67.52 \mathrm{~m}^{2} / \mathrm{g}$ ) & PFOS & $\begin{array}{l}\text { Initial concentration of adsorbent } 400 \mathrm{mg} / \mathrm{L} ; \mathrm{pH} 7 \\
\text { concentration of adsorbate } 0.2 \mathrm{mg} / \mathrm{L}\end{array}$ & $0.29-0.31 \mathrm{mg} / \mathrm{g}$ & [101] \\
\hline Kaolinite (surface area: $11.9 \mathrm{~m}^{2} / \mathrm{g}$ ) & PFOS & $\begin{array}{l}\text { Initial concentration of adsorbent } 5000 \mathrm{mg} / \mathrm{L} ; \mathrm{pH} 7 ; \\
\text { concentration of adsorbate } 0.95 \mathrm{mg} / \mathrm{L}\end{array}$ & $0.08 \mathrm{mg} / \mathrm{g}$ & [102] \\
\hline Alumina (surface area: 88.6 m²/g) & PFOA & $\begin{array}{l}\text { Initial concentration of adsorbent } 10000 \mathrm{mg} / \mathrm{L} ; \mathrm{pH} 4.3 ; \\
\text { concentration of adsorbate } 0.1 \mathrm{mg} / \mathrm{L}\end{array}$ & $0.16 \times 10^{-3} \mathrm{mg} / \mathrm{g}$ & [63] \\
\hline Porous graphite (surface area: $2870 \mathrm{~m}^{2} / \mathrm{g}$ ) & PFOS & $\begin{array}{l}\text { Initial concentration of adsorbent } 100 \mathrm{mg} / \mathrm{L} ; \mathrm{pH} 5 \\
\text { concentration of adsorbate } 100 \mathrm{mg} / \mathrm{L}\end{array}$ & $1240 \mathrm{mg} / \mathrm{g}$ & [103] \\
\hline $\begin{array}{l}\text { Biochar from maize straw (surface area: } \\
\qquad 7.21 \mathrm{~m}^{2} / \mathrm{g} \text { ) }\end{array}$ & PFOS & $\begin{array}{l}\text { Initial concentration of adsorbent } 200-1200 \mathrm{mg} / \mathrm{L} ; \mathrm{pH} 7 \\
\text { concentration of adsorbate } 100 \mathrm{mg} / \mathrm{L}\end{array}$ & $91.6 \mathrm{mg} / \mathrm{g}$ & [104] \\
\hline Chitosan (surface area: $2870 \mathrm{~m}^{2} / \mathrm{g}$ ) & PFOS & $\begin{array}{l}\text { Initial concentration of adsorbent } 1350 \mathrm{mg} / \mathrm{L} ; \mathrm{pH} 3 ; \\
\text { concentration of adsorbate } 50 \mathrm{mg} / \mathrm{L}\end{array}$ & $645 \mathrm{mg} / \mathrm{g}$ & [105] \\
\hline Zeolite) NaY80 surface area, $780 \mathrm{~m}^{2} / \mathrm{g}$ & PFOS & $\begin{array}{c}\text { Initial concentration of adsorbent } 1000 \mathrm{mg} / \mathrm{L} ; \\
\text { concentration of adsorbate } 150 \mathrm{mg} / \mathrm{L} \text {, Particle size: } \\
3-1.2 \mathrm{~mm}\end{array}$ & $114.7 \mathrm{mg} / \mathrm{g}$ & [87] \\
\hline Activated carbon from leaf biomass & $\begin{array}{l}\text { PFOA } \\
\text { PFOS }\end{array}$ & $\begin{array}{l}\text { Modified activated carbons }\left(\mathrm{AC}-\mathrm{H}_{3} \mathrm{PO}_{4}\right) \text { produced } \\
\text { from leaf, uniform particle size of }>64 \mu \mathrm{m}\end{array}$ & $\begin{array}{l}159.61 \mathrm{mg} / \mathrm{g} \\
208.64 \mathrm{mg} / \mathrm{g}\end{array}$ & [106] \\
\hline Boehmite & PFOS & Surface area $299 \mathrm{~m}^{2} / \mathrm{g}$, Average particle size $37.02 \mu \mathrm{m}$ & $0.1529 \mu \mathrm{g} / \mathrm{m}^{2}$ & [108] \\
\hline Alumina nanoparticles & PFOS & Surface area: $83 \mathrm{~m}^{2} / \mathrm{g}$, Particle size: $13 \mathrm{~nm}$ & $\begin{array}{c}\text { At } 30^{\circ} \mathrm{C}: 589 \mathrm{mg} / \mathrm{g} \text {, at } 40^{\circ} \mathrm{C}: 485 \mathrm{mg} / \mathrm{g} \\
\text { at } 50{ }^{\circ} \mathrm{C}: 447 \mathrm{mg} / \mathrm{g}\end{array}$ & [109] \\
\hline
\end{tabular}




\section{The Key Knowledge Gaps and Future Research}

PFOA and PFOS are the most well-known and well-studied PFASs, with an average removal half-life (t1/2) of 5.4 years and 3.8 years, respectively [7]. In order to ensure that the tested results represent real PFAS levels in the examined media, field sampling and laboratory hygiene procedures are important. With many sampling tools used in field and laboratory operations already containing PFAS, the process of sampling and PFAS testing remain uncertain and need lots of effort to alleviate the uncertainty involved. Figure 3 shows the molecular structure of PFOS and PFOA.

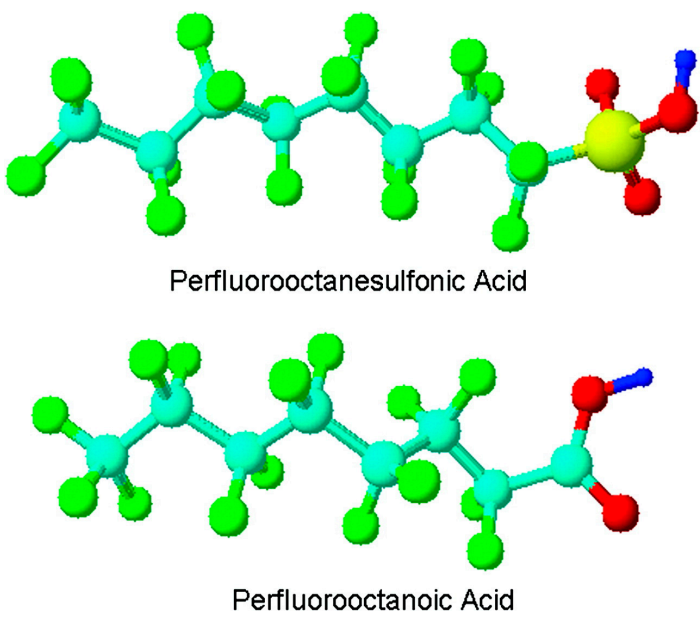

Figure 3. Molecular structures of two representative PFAAs: PFOS and PFOA [8].

Via their fact sheet collection, the Interstate Technology and Regulatory Council (ITRC) outlined site characterization, sampling safeguards, and analytical process concerns and choices. However, for the study of PFAS in surface water, wastewater, non-potable groundwater, and solids, there are currently no validated standard EPA methods [4]. Some US laboratories are applying adapted approaches based on EPA Method 537 for non-drinking water samples. These updated approaches do not have clear sample selection or analytical criteria and have not been checked or analyzed routinely for data quality [110]. As traditional water treatment techniques are unable to effectively remove PFASs, novel treatment methods are urgently needed to remove PFASs in water [92]. Although the intensive effort of phasing out many PFAS products with enforcement of alternative chemical production are in place in many areas across the globe, the risk of PFAS exposures due to the uptake and accumulation in the various media such as ocean and marine food chains as well as groundwater contamination represents a great challenge due to the complexity of the impact timescales [111]. The development and the propagation of the PFAS sites with increased possible exposures to newer PFASs have not been well defined yet.

Despite the agreed health impacts of PFAS particularly on aged or early aged groups, environment, no enforceable national drinking water limits and guidelines are in place in many parts across the globe [33]. There is still limited knowledge around the other PFAS substances. However, there is a growing evidence that these new detected compounds could have same potential on human health and may pose similar risks to human and the environment [33,112]. The use of engineered pre-treatment or post-treatment approaches must be based on a 'fit for purpose' definition and carefully combined with the planned water end use concept in order to make sure that both human and environmental health threats are properly managed and treated [21].

Another main challenge in PFAS potential health impact with considerable complexity was reported by Gebbink et al. [112]. They found that in samples collected from food, not only the PFOS and PFOA levels were overestimated by an order of magnitude, but also there is still a knowledge gap 
in identifying the precise percentage of these precursors can contribute to human PFCA exposure since the exposure pathway remains undefined [112].

In order to evaluate the development of degradation products and potentially undesirable by-products to track the occurrence of compounds in the gas process and to demonstrate the efficacy of treatment for other types of pollutants and to apply them to different types of water, further research is required. Whilst many studies demonstrate the link between PFAS exposure and the deteriorated immune system particularly in children, there is little evidence to map other health impacts, including cancer, as it is only noticeable in areas with exceptionally high exposures, with inadequate data to correlate these exposures to PFAS with neurodevelopment [111].

\subsection{Risks Associated by PFAS}

The developing use of the PFAS in various commercial and industrial sectors including aqueous fire-fighting foam, disposable food packaging, furniture, carpets, cookware, water treatment and many others poses a potential risk to the environment $[15,16,49]$. Like many other contaminants, PFAS can accumulate into the environment by either a direct or indirect pathway [113]. Direct sources and PFAS contamination released from different industries including wastewater treatment plants, sludge disposal, and landfill sites [4]. There are more than 4000 bioavailable PFAS compounds in the globe, however, the toxicity values for most of these compounds are still poorly understood with only few PFAS compounds have defined toxicity values and level [32]. Risk assessment aims at developing health-based guideline levels upon intensive review of PFAS toxicological level that cause harm to humans. PFOS was viewed as Persistent Organic Pollutant (POP) by the Conference of Parties, Stockholm Convention in 2009 where EPA has characterized PFOA as a "likely carcinogen" and its use was restricted [98]. Unfortunately, this PFAS toxicity level is still poorly understood and this has created the need to develop defined hazardous and risk registry for the PFAS toxicity values. This seems to be among the great challenges for the majority of PFAS compounds [53].

\section{Human Exposure Pathways}

The first ever published data about widespread PFOS in the environment was reported in 2001 by [6] where PFOS was found in fish and birds tissues as well as marine mammals. The finding revealed that the level of PFOS in animals is proportionally related with the population density and the industrialized activities. As such animals in these areas have much higher PFOS level than those live in remote marine areas [6,30]. Another pathway was found through the food chain where fish eating animals such as mink and bald eagles proved to have greater levels of PFOS than in their diets. Another toxicity realization of PFAS was introduced when PFAS compounds were reported in blood samples from various samples around the globe [32]. Potential health risks associated with PFAS exposure and the concern regarding their bioaccumulation indicated the tendency towards the potential exposure through various media and various sources. A study of consumer exposure using a scenario-based approach to PFOS and PFOA conducted by Trudel et al. [30] revealed an everyday exposure to PFAS is taking place in many countries resulting in the long-term uptake of PFOS and PFOA of 3-220 and 1-130 ng per kg body weight per day, respectively [30]. Many health impacts including cancer, liver damage, and immune system failure have been linked to the PFAS [113,114]. Moreover, whilst the routes of PFAS exposure remains somehow unclear, research agrees that diet is a potentially main source and well-established research suggests that PFOA is absorbed via inhalation and ingestion $[30,115]$.

Human exposure pathways for PFOS, PFOA, and other PFAS related substances through various routes including drinking water, indoor polluted environment, food chain, long term contact with industries that produce PFAS compound including food packaging or cookware, breast milk, airborne dust, and air [1,116]. All of which result in cumulative uptake and PFAS build up [18,23,29]. This persistent exposure to PFAS can be poorly reversible due to slow elimination kinetics as well as the ongoing build up regardless of its magnitude and bioaccumulation potential [23]. China, for example, 
has witnessed a surge in PFAS release in the last decade due to the evolving industrial activities. The release of PFOS in China from industrial sources in 2010 was estimated by about 70 ton which is six times greater than the reported PFAS release in 2008 [20]. Table 6 shows the PFAS source- pathway and receptors.

Table 6. PFAS Source- Pathway and receptors.

\begin{tabular}{ccc}
\hline Sources & Exposure Pathways & Receptors \\
\hline & Soil & Ecological \\
Industrial and wastewater effluents Packaging & Biosolids & Aquatic \\
Consumer products Landfills & Dust & Benthic \\
Fire-fighting foams & Sediment & Terrestrial \\
& Surface water Groundwater & Avian \\
& Drinking water & Human \\
\hline
\end{tabular}

Inappropriate treatment and disposal of waste and wastewater proved to pose significant PFAS risk and contamination [110]. Indirect PFAS generation and contamination take place through the transformation of perfluoroalkyl precursors and the breakdown of perfluoroalkyl-based products [116]. Both direct and the indirect PFAS generation can pose high contamination and risk to the surrounding environment including air and drinking water contamination, food poisonous where PFAS have been identified as a potential threat to public health [117]. The great effort made to counter the propagation of PFAS levels in various receptors resulted in PFOS and PFOA declines by $32 \%$ and $25 \%$, respectively, in early 2000. Yet, other PFAS compounds continue to increase, suggesting various and more strict measures to quarantine the spread of the PFAS compounds [49]. This was evident through a long monitoring program of PFAS concentration in human blood in Norway (1977-2006) which resulted in the conclusion that PFAS levels increased by more than nine times in men aged between 40 and 50 years old over this period of time, pointing to the rapid development of PFAS contamination and therefore the increasing potential risks [49].

Due to their high solubility and high persistence, PFAS compounds can migrate in air and water bodies leading to concentrated level in environment and therefore, pose high risk and toxicity on public health [49]. This increasing aquatic bioaccumulation, soil/groundwater uptake, fish, seafood, meat, and vegetables were identified as the most PFAS sources that human can uptake at various levels [31]. On the other hand, soil contamination is one of the main environmental impacts due to PFAS spread. Research suggests that PFAS risk is associated with a range of impacts on ecosystem services. Although the impact and the risk of PFAS still not fully understood due to the poor evidence of the linkage between human public health and PFAS levels, previous research has found the exposure to PFAS including PFOA may delay bone development and accelerated male puberty in mice [5]. However, the adverse health effects of PFOA and some other compounds have been confirmed by several researchers $[8,31,110]$.

PFAS proved to have high resistant to temperature and bio accumulative [118]. Recently, research has found that humans are normally have a long half-life of serum elimination of PFOS, PFHS, and PFOA with the recent realization of considerable PFAS levels in various media including fish, birds, mammals and human blood seems to be alarming and call for urgent intervention to alleviate any further degradation in the public health as well as the ecosystem $[17,18,118,119]$. Niu et al. [119] found that PFAS compounds, including PFOS and PFOA, pose a high risk to human and public health. The high linkage between the PFOS and PFOA and neuropsychological development in children was investigated and realized by Niu et al. [119]. They found that the PFOS and PFOA increased the risk of development problem and had significant impact on human health including the personal-social skills particularly among females $[7,119]$. The recent discovery proved that PFOA has been linked to the increased incidence of weight loss and even a disturbance in lipid system when the tests were conducted on laboratory animals [118]. Moreover, recent research on animals 
suggested that PFAO and PFOS are among the main causes of cancer where the two compounds were classified as carcinogenic substances. The same effect on humans is suggested by the World health Organization (WHO) who found that both PFOA and PFOS are potential carcinogenic materials to human bodies [111]. Other studies found high linkage between PFOA exposure and high cholesterol leading to liver enzymes and kidney cancer [110]. Other studies have found increasing level of PFOS and PFOA in the blood samples of human population and wildlife reflecting that severity of the exposure to the widespread of PFAS chemicals [8]. Another good evidence of PFAS exposure and potential risk was reported by the ATSDR [8] where blood serum concentrations with high PFOS and PFOA level were found in workers living near potential PFAS facilities and industries compared with normal population [8].

In summary, despite the many trials to limit the PFAS spread and the endorsement of phasing out the main PFAS substances (expressed in PFOS and PFOA), other compounds including PFAAs and related substances are still widely used in various industries including fire-fighting foams, photographic, semiconductor and others [20]. Therefore, the detection of PFAS in human bodies have not decreased [20,31,32,49]. Research has found the level of adverse health impact with the level of significance are depending on the extent of exposure, the duration, and the persistence [10].

A study by the French total diet [112] found that mothers are likely to provide a pathway of PFAO to their children through breast feeding where PFOA was noticed in $77 \%$ of the breast milk samples at an average level of $0.041 \mathrm{ng} / \mathrm{mL}$ and a maximum level of $0.308 \mathrm{ng} / \mathrm{mL}$ [119]. Also, because of the their immature developing immune system and fast body growth, children are probably much more sensitive to the impacts of PFAS [8]. A more valid link between PFAO and the adverse human health was realized when a sample of around 69,000 people in the Mid-Ohio Valley were tested for PFAS as the analysis of the water supply system there revealed a considerable level of PFAO (>50 ng/L of PFOA) [5].

\section{PFAS Water Quality Guidelines}

\subsection{Current Llegislations and Practices in Various Countries}

PFAS guideline threshold values are affected by several factors, including social, political, and economic influences [5]. The variation in the regulatory values of PFAS across different guidelines can be easily addressed. One of the main reasons is the differences in toxicology decisions and differences in exposure parameters [4]. Moreover, PFAS compounds encounter both temporal and spatial variation and as emerging contaminants, the regulations are rapidly changing to account for the developing knowledge. However, the protection of the human health remains the main focus of the PFAS regulations and guidance across all regulations and standards [4]. The Interstate Technology and Regulatory Council (ITRC) indicated the significant variation in PFAS regulations by identifying the states that have different guideline for PFOA and/or PFOS levels in drinking water and groundwater from EPA's health advisories (HAs) [4]. One main reason for that is due to the different bodies that regulate the PFAS. Whilst the environmental perspectives of PFAS is regulated by the (EPA). Toxic Substances Control Act (TSCA), their use in food is regulated by FDA which is normally associated by lack of certain scientific evidence on their hazardous impact and exposure rate [120-122]. Despite the drinking water contamination is an ongoing major issue, it is somehow puzzling that until now there seem to be no federal PFAS drinking water standards in the USA. The absence of such federal PFAS regulations has led multiple US states to develop specific water guidelines which can support the decisions regarding the cleaning of the contaminated site as well as drinking water surveillance and treatment [5]. Until recently, no MCLs were established for PFAS chemicals although great efforts are being made towards initiating MCL for PFOA and PFOS by the EPA and other agencies.

This lack of evidence between the public heath adverse impacts and the PFAS level has resulted in undefined epidemiological evidence which in turns created considerable variation among the different water guidelines due to the uncertainties involved [5]. There is still uncertainty around the potential 
PFAS risk to the human health due to the limited data on how people are exposed to the PFAS and for how long. The exposure level and the consequences of this exposure are also poorly understood [53].

The need for extensive research to alleviate this uncertainty and how the PFAS impact the health risk is still among the top priorities in order to expect a safe exposure for humans. Until now, the authors are aware that there is still urgent need to conduct more research in the areas of PFAS toxicity and exposure as this remains one of the knowledge gaps in PFAS field. This is obvious since the first US EPA preliminary drinking water health advisory level towards the negative impacts of PFOS and PFOA was released before PFAS became a public issue in 2015 upon the growing public trend towards limiting PFAS release. This was upon the realization of the PFAs toxicity. More recent guidelines referring to the PFAS as a significant toxic substance were published by USEPA in 2019. Unfortunately, PFAS legislations and regulations are challenged by the significant differences across PFAS compounds associated with the limited information that can be utilized to establish uniform legislations across the globe [110].

Another main concern is the influence of the manufacturing companies and the bias attitude that some researcher may have depending on the interest of the funding agencies. Cordner et al. [5] indicated that economic factors play vital role in directing the guideline levels where a case of litigation was revealed by Minnesota Attorney General against $3 \mathrm{M}$ when the company used a scientific researcher to manipulate others research findings and undermine the health impact of PFAS in what was considered as a violation of scientific norms [5].

\subsection{EPA-US Guidelines}

USEPA has released non-regulatory concentrations of PFAS that addresses the PFAS health impact in reference to the exposure time. Since 2006, EPA has reviewed and regulated around 191 PFAS compounds through a combination of orders [110]. According to the EPA, the lifetime health advisory (LHA) of $70 \mathrm{ng} / \mathrm{L}$ for PFOA and PFOS in drinking water is set as guideline. This LHA is applicable to PFOA and PFOS individually while it is applicable to the sum of both compounds in the case of accidental High concentration as in the case of Australian standards [4]. This value seems to be less conservative compared with other global regulations. The global focus on the PFAS was developed rapidly since 2002 where more conservative levels were in place due to the growing concerns. More restrictions were placed on the "long chain" (C8) molecule PFOS as it was withdrawn from markets. However, the current regulation seem to be driven by many factors including financial factors, detection limit and many others [5,121]. In 2016, the EPA suggested its lifetime limit for PFOA and PFOS of $70 \mathrm{ng} / \mathrm{L}$, individually or combined. However, some US states argued that EPA's guidelines are insufficient and does not address the potential associated health risk and hence various PFAS threshold values were developed different from the EPA ones. The state's water guideline levels for PFOA and/or PFOS ranged from 13 to $1000 \mathrm{ng} / \mathrm{L}$ compared with $70 \mathrm{ng} / \mathrm{L}$ by the EPA for both compounds individually and combined (Table 7). For example, Minnesota established state guideline levels that were lower than the EPA guidelines of $35 \mathrm{ng} / \mathrm{L}$ PFOA and $27 \mathrm{ng} / \mathrm{L}$ PFOS. On the other hand, New Jersey has proposed $14 \mathrm{ng} / \mathrm{L}$ MCLs for PFOA and $13 \mathrm{ng} / \mathrm{L}$ for PFOS, the first lowest guideline standard in the US [5].

In USA, MCLs for any PFAS have not been identified by EPA, though they recently declared their intention to "initiate steps to evaluate the need for a maximum contaminant level (MCL) for PFOA and PFOS". Identifying the MCL would increase the ability of EPA's authority to study further on PFAS pollution [119]. In May 2016, USEPA lowered its drinking water health standard to $0.07 \mu \mathrm{g} / \mathrm{L}$ for the two most frequently found PFAS, PFOA and PFOS. A lifetime drinking water health advisory (HA) for PFOA was issued by the USEPA on the basis of a reference dose (RFD) of 0.07 micrograms per liter $(\mu \mathrm{g} / \mathrm{L})$ based on a developmental toxicity analysis in mice [7]. The toxicity values of PFAS are site specific with the highly likely temporal and spatial variation of these values. Moreover, the rapidly developed analytical methods represents another challenge with the rapid changing regulations. 
Some toxicity values are varying from one standard to another and there are no uniform standard PFAS toxicity values across all countries.

Table 7. US PFAO/PFOS drinking water guideline levels (After [5]).

\begin{tabular}{ccccc}
\hline \multirow{2}{*}{\begin{tabular}{c} 
Guideline \\
\cline { 2 - 5 }
\end{tabular}} & PFAO (ng/L) & PFOS (ng/L) & PFAO (ng/kg-Day) & PFOS (ng/kg-Day) \\
\hline $\begin{array}{c}\text { U.S. EPAa, 2016, Health Advisory } \\
\text { Level }\end{array}$ & 70 & 70 & 20 & 20 \\
\hline $\begin{array}{c}\text { Alaska DECb, 2016, Groundwater } \\
\text { cleanup level }\end{array}$ & 400 & 400 & 20 & 20 \\
\hline $\begin{array}{c}\text { Maine DEPb, 2016, Remedial action } \\
\text { guideline }\end{array}$ & 130 & 560 & 6 & 50 \\
\hline $\begin{array}{c}\text { Minnesota DOH, 2017, Noncancer } \\
\text { health-based level }\end{array}$ & 35 & 27 & 18 & 1.8 \\
\hline $\begin{array}{c}\text { New Jersey DEP, 2017, Maximum } \\
\text { contaminant level }\end{array}$ & 14 & 13 & 2 & NA \\
\hline $\begin{array}{c}\text { North Carolina DENRb, 2012, Interim } \\
\text { maximum allowable concentration }\end{array}$ & 1000 & - & N/A & 20 \\
\hline $\begin{array}{c}\text { Texas CEQb, 2017, Protective } \\
\text { concentration level }\end{array}$ & 290 & 560 & 15 & 20 \\
\hline $\begin{array}{c}\text { Vermonta DEC/DOH,6 2016, Primary } \\
\text { groundwater enforcement standard }\end{array}$ & 20 & 20 & 20 & 201 \\
\hline
\end{tabular}

EU guidelines just recently has initiated a preliminary guideline on maximum allowable PFAS concentrations. In Germany, a health-based guidance of maximum PFAS level was proposed by the drinking water commission under the Ministry of Health. The proposed value is based on the safe lifelong exposure for all population groups of $300 \mathrm{ng} / \mathrm{L}$ for both PFOA and PFOS. In Germany, upon the detection of PFOA in drinking water at concentrations up to $0.64 \mathrm{~g} / \mathrm{L}$, the German Drinking Water Commission (TWK) established the first health based lifelong PFAO and PFOS exposure of $0.3 \mathrm{~g} / \mathrm{L}$ in drinking water in June 2006 [40]. Until recently, Italy, has no PFAS guidelines in drinking water and the PFAS regulations were introduced upon the extreme detection of PFAS in water bodies in an area of the Veneto Region [38]. The highest amount of PFAS in drinking water was enforced by the Italian National Health Institute to protect human's health risk with PFOS $\leq 30 \mathrm{ng} / \mathrm{L}, \mathrm{PFOA} \leq 500 \mathrm{ng} / \mathrm{L}$, and other PFAS $\leq 500 \mathrm{ng} / \mathrm{L}$. In Spain, frequent PFAS monitoring programs were carried out and water samples were regularly tested for various PFAS substance. PFAS level varied across Spain with the conclusion of an unlikely health risk under the detected PFOS and PFOA levels where the maximum average levels of PFOS and PFOA were 1.81 and $2.40 \mathrm{ng} / \mathrm{L}$, respectively [39].

Canada has developed federal guidelines for a few PFAS levels to avoid any potential human health affect, while values to safeguard ecological receptors are offered for PFOS (Table 8) [118]. An in-depth study was carried out on ecotoxicology and toxicology, environmental fate and behavior, and exposure. In order to initiate toxicological reference values (TRVs), adequate information on the PFAS impact was obtained, while ECCC assessed the suitability of obtainable non- or low-effect ecotoxicological data for the derivation of PFOS recommendations for multiple matrices for the safety of different trophic levels. The degree of PFAS in drinking water, soil, groundwater, and bird eggs are now available in the Canadian PFAS regulation. 
Table 8. Health based guidance for usage in field investigation in Canada [110].

\begin{tabular}{ccc}
\hline PFAS Name & Acronym & $\begin{array}{c}\text { Drinking Water Screening Value } \\
\text { (ng/L) }\end{array}$ \\
\hline $\begin{array}{c}\text { perfluorobutanoate } \\
\text { perfluorobutane sulfonate }\end{array}$ & PFBA & 30 \\
perfluorohexanesulfonate & PFBS & 15 \\
perfluooropentanoate & PFHxS & 0.6 \\
perfluorohexanoate & PFHxA & 0.2 \\
perfluoroheptanoate & PFHpA & 0.2 \\
perfluorononanoate & PFNA & 0.2 \\
fluorotelomer sulfonate & $6: 2$ FTS & 0.02 \\
fluorotelomer sulfonate & 8:2 FTS & 0.2 \\
\hline
\end{tabular}

In Australia, PFASs have been widely used in several industrial applications. PFAS health-based guidance values for PFOS, PFOA and PFHxS, were developed by The Department of Health, Food Standards Australia (Table 9). The inconsistent release of PFAS in the environment with the multiple PFAS sources have created additional barrier in PFAS management. The knowledge gap regarding the PFAS spread in the Australian environment made the process of setting definite guidelines a bit complex. Gallen et al. [24], for example, found that the level of PFAS in in the treated WWTP effluent was higher than the wastewater influence.

Table 9. Health based guidance for utilization in site investigation in Australia [122].

\begin{tabular}{cccc}
\hline Health Based Guideline Value & $\begin{array}{c}\text { PFOS and PFHxS } \\
\text { (ng) }\end{array}$ & $\begin{array}{c}\text { PFOA } \\
\text { (ng) }\end{array}$ & $\begin{array}{c}\text { PFAO } \\
\text { (ng) }\end{array}$ \\
\hline Tolerable daily intake & 20 & 160 & 0.16 \\
Guideline for drinking water quality & 70 & 560 & 0.56 \\
Guideline value for Recreational water quality & 2000 & 10,000 & 10 \\
\hline
\end{tabular}

The guideline values considered the health of the general community due to the PFAS exposure due water and food consumption [122]. Through an intergovernmental agreement (IGA), Australia has been forced to agree on a National Structure for Reacting to PFAS contamination to restrict the spread of PFAS contamination due to increasing concerns about the risk of PFAS. Under the IGA, Australians have followed a policy to respond to PFAS pollution, introduced national environmental management of PFAS, and implemented guidelines to advise government agencies involved in responding to PFAS contamination. The guidance values based on health indicate the threshold value of the amount of PFAS in food or drinking water that an individual can consume without being affected over a lifetime.

\section{Factors Contributing to Variation in PFAS Guideline Levels}

Since the guidelines are always driven by the toxicology and the risk values identified by the human body, the regulations for PFA substances were viewed to limit the potential health impact and risk. Data obtained from toxicity tests in China showed that the criteria maximum concentration (CMC) for protection of aquatic organisms were 3.78 and $45.54 \mathrm{mg} \cdot \mathrm{L}^{-1}$ for PFOS and PFAO, respectively which is higher than values derived in North America [20]. This variation indicates the challenges in setting out uniform PFAS guideline values due to the prevailing uncertainty in risk assessment and the lack of solid scientific background. Moreover, PFAS regulations are also influenced by the technical capacity and other socio-economic factors involved. There is a developing concern towards PFASs regulations due to the growing frequent detection of PFAS in drinking water in the US. The USEPA has issued a long-term health advisory PFAs level in drinking water of $70 \mathrm{ng} / \mathrm{L}$ (for combination of PFOS and/or PFOA). This regulation is intended to lower the number of individual PFASs reported. However, these guidelines of PFAS in drinking water have been dropped to $70 \mathrm{ng} / \mathrm{L}$ by many states, as in the case of New Jersey where a maximum PFAS level for PFOS was set at $13 \mathrm{ng} / \mathrm{L}$ and a $14 \mathrm{ng} / \mathrm{L}$ 
target for PFOA proposed [7]. Other states including California have adopted the same while the State of New York made it even lower with a maximum allowable PFAS value of $10 \mathrm{ng} / \mathrm{L}$ for PFOS and PFOA. Some other states went even for lower maximum allowable PFAS as in the case of New Hampshire and Michigan with an MCL of $12 \mathrm{ng} / \mathrm{L}$ for PFOA and $16 \mathrm{ng} / \mathrm{L}$ health-based value for PFO, respectively [7]. Much more conservative and lower levels of PFAS were proposed by Denmark, with a temporary level of $3 \mathrm{ng} / \mathrm{L}$ for PFOS being considered. The challenge in setting out these regulatory values remains the technical capacity in providing proper detection levels as well as the applicability of meeting these targets with the development of industrial activities and the lack of knowledge in identifying the toxicology of PFAs at these levels.

\section{Conclusions}

The intensive and the widespread nature of industries that are heavily releasing PFAS substances has contributed to a PFAS build up in the environment which presents a serious threat to human life. Occasional mysterious PFAS release, fate, transport, and exposure by many industries are adding more complexity for the policymakers. While the pathway of PFAS is still not very clear, PFAS characterization and behavior need to be better explained, particularly in terms of occurrence, transformation, and degradation pathway.

Although PFAS has been linked to various health risks, such as cancer, liver damage, and hormone disruption, the extent of this risk remains uncertain. This is due to the poor understanding of the risk scale resulting from the exposure frequency as well as the severity and the exposure duration. Since the PFAS in soil can leach down to great depths (around $15 \mathrm{~m}$ ), PFOS levels in soil have been advised by governments including Australia to have a maximum of $20 \mathrm{ng} / \mathrm{g}$ for land uses and industry, which vary according to the land use. This leaching potential is getting more evident in case of point source pollution areas including landfill and treatment plants. However, the retention of PFOS increases with the clay content and the organic matter as well as the decrease of soil $\mathrm{pH}$.

There is an ongoing effort by many governments to phase out PFAS substances and find alternatives to PFAS substances. This effort has caused PFAS levels to decline particularly in surface water. Whilst the alternative chemicals should be less toxic and not persist in the environment, the phasing out process has not resulted in PFAS elimination or decrease where many new industries are prone to PFAS release. This may require extra effort in understanding the measures to phase out.

It is concluded that the longer the exposure to PFAS compound, the higher the risk is due to the ubiquitous uptake of PFAS. PFAS high doses uptake. There is still a lack of precise knowledge around the PFAs toxicology and the threshold values at which PFAs can pose severe health risk. Moreover, this link is still lacking the interpretation of the relationship between the extent of the PFAS exposure and the associated impact, where no specific data can explain the impact of longevity, frequency, and severity of this impact. While the guidelines agree on considering human health as a base for any regulatory values, there seems to be a significant variation across the global guidelines in setting unified PFAS standards since the PFAS level and rate are inconsistent within the same country and across the globe. These discrepancies stem from the differences in PFAS sources, toxicology decisions, and exposure rates where PFAS compound can transform from one compound to another as well as transport with sediment and water far from the source based on the surrounding environment and therefore creating temporal and spatial variation. The review highlighted the need for further research towards identifying the characteristics, fate, frequency, and the severity of PFAS represented by the exposure time and extent to better understand the nature of PFAS pathways and exposure.

Author Contributions: Idea, Z.A.; conceptualization, M.J.K.B., Z.A., M.Y.D.A.; writing-impact on drinking water, M.Y.D.A., writing — treatment technologies, M.J.K.B.; writing-regulations and measurement-based data collected from various countries, Z.A.; formatting and conclusion M.J.K.B., M.Y.D.A. All authors have read and agreed to the published version of the manuscript.

Funding: The authors declare this research has no funding.

Conflicts of Interest: The authors declare no conflict of interest. 


\section{References}

1. Buck, R.C.; Franklin, J.; Berger, U.; Conder, J.M.; Cousins, I.T.; de Voogt, P.; Jensen, A.A.; Kannan, K.; Mabury, S.A.; van Leeuwen, S.P. Perfluoroalkyl and PolyfluoroalkylSubstances in the Environment: Terminology, Classification, and Origins. Integr. Environ. Assess. Manag. 2011, 7, 513-541. [CrossRef] [PubMed]

2. Fu, Y.; Wang, T.; Wang, P.; Fu, Q.; Lu, Y. Effects of age, gender and region on serum concentrations of perfluorinated compounds in general population of Henan, China. Chemosphere 2014, 110, 104-110. [CrossRef] [PubMed]

3. Clout, L.; Priddle, D.; Spafford, P.J. The Coalition against PFAS. 2018. Available online: https://cappfas.com/ what-is-pfas/ (accessed on 19 December 2020).

4. ITRC. PFAS Technichal and Regulatory Guidanace Document and Fact Sheet PFAS-1; ITRC: Washington, DC, USA, 2020. [CrossRef]

5. Cordner, A.; de la Rosa, V.Y.; Schaider, L.A.; Rudel, R.A.; Richter, L.; Brown, P. Guideline levels for PFOA and PFOS in drinking water: The role of scientific uncertainty, risk assessment decisions, and social factors. J. Expo. Sci. Environ. Epidemiol. 2019, 29, 157-171. [CrossRef] [PubMed]

6. Giesy, J.P.; Kannan, K. Global Distribution of Perfluorooctane Sulfonate in Wildlife. Environ. Sci. Technol. 2001, 35, 1339-1342. [CrossRef] [PubMed]

7. USEPA. Drinking Water Health Advisories for PFOA and PFOS.; USEPA: Washington, DC, USA, 2016; pp. 1-4. Available online: https://www.epa.gov/sites/production/files/201605/documents/pfos_health_advisory_finalplain.pdf (accessed on 10 October 2020).

8. ATSDR. Toxicological Profile for Perfluoroalkyls (Draft for Public Comment); Agency for Toxic Substances and Disease Registry: Atlanta, GA, USA, 2018. Available online: https://www.atsdr.cdc.gov/toxprofiles/tp.asp? $\mathrm{id}=1117 \& \mathrm{tid}=237$ (accessed on 28 October 2020).

9. Fàbrega, F.; Kumar, V.; Schuhmacher, M. PBPK modeling for PFOS and PFOA: Validation with human experimental data. Toxicol. Lett. 2014, 230, 244-251. [CrossRef]

10. Lake, N.; Cao, Y.; Cao, X.; Wang, H.; Wan, Y.; Wang, S. Assessment on the distribution and partitioning of perfluorinated compounds in the water and sediment. Environ. Monit. Assess. 2015, 611, 611. [CrossRef]

11. Zareitalabad, P.; Siemens, J.; Hamer, M.; Amelung, W. Perfluorooctanoic acid (PFOA) and perfluorooctanesulfonic acid (PFOS) in surface waters, sediments, soils and wastewater-A review on concentrations and distribution coefficients. Chemosphere 2013, 91, 725-732. [CrossRef]

12. Post, G.B.; Louis, J.B.; Cooper, K.R.; Boros-Russo, B.J.; Lippincott, R.L. Occurrence and Potential Significance of Perfluorooctanoic Acid (PFOA) Detected in New Jersey Public Drinking Water Systems. Environ. Sci. Technol. 2009, 43, 4547-4554. [CrossRef]

13. Jain, R.B. Time trends over 2003-2014 in the concentrations of selected perfluoroalkyl substances among US adults aged $\geq 20$ years: Interpretational issues. Sci. Total Environ. 2018, 645, 946-957. [CrossRef]

14. Liu, B.; Zhang, H.; Li, J.; Dong, W. Perfluoroalkyl acids (PFAAs) in sediments from rivers of the Pearl River Delta, southern China. Environ. Monit. Assess. 2017, 189, 213. [CrossRef]

15. Dunn, A.M.; Hofmann, O.S.; Waters, B.; Witchel, E. Cloaking malware with the trusted platform module. In Proceedings of the 20th USENIX Security Symposium, San Francisco, CA, USA, 8-12 August 2011; pp. 395-410.

16. Vedagiri, U.K.; Anderson, R.H.; Loso, H.M.; Schwach, C.M. Ambient levels of PFOS and PFOA in multiple environmental media. Remediat. J. 2018, 28, 9-51. [CrossRef]

17. Goosey, E.; Harrad, S. Perfluoroalkyl compounds in dust from Asian, AustralianEuropean, and North American homes and UK cars, classrooms, and offices. Environ. Int. 2011, 37, 86-92. [CrossRef] [PubMed]

18. ITRC. Environmental Fate and Transport for per-and Polyfluoroalkyl Substances; ITRC: Washington, DC, USA, 2018; Available online: https://pfas-1.itrcweb.org/wp-content/uploads/2018/03/pfas_fact_sheet_fate_and_ transport_3_16_18.pdf (accessed on 28 October 2020).

19. Kucharzyk, K.H.; Darlington, R.; Benotti, M.; Deeb, R.; Hawley, E. Novel treatment technologies for PFAS compounds: A critical review. J. Environ. Manag. 2017, 204, 757-764. [CrossRef] [PubMed]

20. Wang, T.; Wang, P.; Meng, J.; Liu, S.; Lu, Y.; Khim, J.S.; Giesy, J.P. A review of sources, multimedia distribution and health risks of perfluoroalkyl acids (PFAAs) in China. Chemosphere 2015, 129, 87-99. [CrossRef] 
21. Page, D.; Vanderzalm, J.; Kumar, A.; Cheng, K.Y.; Kaksonen, A.H.; Simpson, S. Risks of perfluoroalkyl and polyfluoroalkyl substances (PFAS) for sustainable water recycling via aquifers. Water 2019, 11, 1737. [CrossRef]

22. Gallen, C.; Drage, D.; Eaglesham, G.; Grant, S.; Bowman, M.; Mueller, J.F. Australia-wide assessment of perfluoroalkyl substances (PFASs) in landfill leachates. J. Hazard. Mater. 2017, 331, 132-141. [CrossRef]

23. Cousins, I.T.; Vestergren, R.; Wang, Z.; Scheringer, M.; McLachlan, M.S. The precautionary principle and chemicals management: The example of perfluoroalkyl acids in groundwater. Environ. Int. 2016, 94, 331-340. [CrossRef]

24. Gallen, C.; Eaglesham, G.; Drage, D.; Nguyen, T.H.; Mueller, J.F. A mass estim Figure 2020 ate of perfluoroalkyl substance (PFAS) release from Australian wastewater treatment plants. Chemosphere 2018, 208, 975-983. [CrossRef]

25. Domingo, J.L.; Nadal, M. Human exposure to per-and polyfluoroalkyl substances (PFAS) through drinking water: A review of the recent scientific literature. Environ. Res. J. 2019, 177, 108648. [CrossRef]

26. Gonzalez, D.; Thompson, K.; Quiñones, O.; Dickenson, E.; Bott, C. Assessment of PFAS fate transport, and treatment inhibition associated with a simulated AFFF release within a WASTEWATER treatment plant. Chemosphere 2021, 262, 127900. [CrossRef]

27. Simon, J.A.; Cassidy, D.; Cherry, J.; Bryant, D.; Cox, D. PFAS Experts Symposium: Statements on regulatory policy, chemistry and analytics, toxicology, transport/fate, and remediation for per- and polyfluoroalkyl substances (PFAS) contamination issues. Remediat. J. 2019, 29, 31-48. [CrossRef]

28. Cerveny, D.; Grabic, R.; Fedorova, G.; Grabicova, K.; Turek, J.; Zlabek, V.; Randak, T. Fate of perfluoroalkyl substances within a small stream food web affected by sewage effluent. Water Res. 2018, 134, 226-233. [CrossRef] [PubMed]

29. Brusseau, M.L. Assessing the potential contributions of additional retention processes to PFAS retardation in the subsurface. Sci. Total Environ. 2018, 613-614, 176-185. [CrossRef] [PubMed]

30. Trudel, D.; Horowitz, L.; Wormuth, M.; Scheringer, M.; Cousins, I.T.; Hungerb, K. Estimating Consumer Exposure to PFOS and PFOA. Risk Anal. 2008, 28, 13-15. [CrossRef]

31. Sznajder-katarzy, K.; Surma, M.; Cie, I. A Review of Perfluoroalkyl Acids (PFAAs) in terms of Sources, Applications, Human Exposure, Dietary Intake, Toxicity, Legal Regulation, and Methods of Determination. J. Chem. 2019, 2019. [CrossRef]

32. Uebelacker, L.A. A Review of the Pathways of Human Exposure to Poly- and Perfluoroalkyl Substances (PFASs) and Present Understanding of Health Effects Elsie. Physiol. Behav. 2017, 176, 139-148. [CrossRef]

33. Pelch, K.E.; Reade, A.; Wol, T.A.M.; Kwiatkowski, C.F. Review article PFAS health e ff ects database: Protocol for a systematic evidence map. Environ. Int. J. 2019, 130, 104851. [CrossRef]

34. Zhao, L.; Zhu, L.; Zhao, S.; Ma, X. Sequestration and bioavailability of perfluoroalkyl acids (PFAAs) in soils: Implications for their underestimated risk. Sci. Total Environ. 2016, 572, 169-176. [CrossRef]

35. Yan, H.; Cousins, I.T.; Zhang, C.; Zhou, Q. Perfluoroalkyl acids in municipal landfill leachates from China: Occurrence, fate during leachate treatment and potential impact on groundwater. Sci. Total Environ. 2015, 524-525, 23-31. [CrossRef]

36. Eriksson, U.; Kärrman, A.; Rotander, A.; Mikkelsen, B.; Dam, M. Perfluoroalkyl substances (PFASs) in food and water from Faroe Islands, Environ. Sci. Pollut. Res. 2013, 20, 7940-7948. [CrossRef]

37. Lu, Z.; Lu, R.; Zheng, H.; Yan, J.; Song, L.; Wang, J.; Yang, H. Risk exposure assessment of per-and polyfluoroalkyl substances (PFASs) in drinking water and atmosphere in central eastern China. Environ. Sci. Pollut. Res. 2018, 25, 9311-9320. [CrossRef] [PubMed]

38. Mastrantonio, M.; Bai, E.; Uccelli, R.; Cordiano, V.; Screpanti, A.; Crosignani, P. Drinking water contamination from perfluoroalkyl substances (PFAS): An ecological mortality study in the Veneto Region, Italy. Eur. J. Public Health 2017, 28, 180-185. [CrossRef] [PubMed]

39. Domingo, J.L.; Ericson-jogsten, I.; Perello, G.; Nadal, M.; van Bavel, B.; Ka, A. Human Exposure to Perfluorinated Compounds in Catalonia, Spain: Contribution of Drinking Water and Fish and Shellfish. Agric. Food Chem. 2012, 60, 4408-4415. [CrossRef] [PubMed]

40. Wilhelm, M.; Bergmann, S.; Dieter, H.H. Occurrence of perfluorinated compounds (PFCs) in drinking water of North Rhine-Westphalia, Germany and new approach to assess drinking water contamination by shorter-chained C4-C7 PFCs. Int. J. Hyg. Environ. Health 2010, 213, 224-232. [CrossRef] [PubMed] 
41. Schwanz, T.G.; Llorca, M.; Farré, M.; Barceló, D. Perfluoroalkyl substances assessment in drinking waters from Brazil, France and Spain. Sci. Total Environ. 2016, 539, 143-152. [CrossRef] [PubMed]

42. Quinete, N.; Wu, Q.; Zhang, T.; Yun, S.H.; Moreira, I.; Kannan, K. Specific profiles of perfluorinated compounds in surface and drinking waters and accumulation in mussels, fish, and dolphins from southeastern Brazil. Chemosphere 2009, 77, 863-869. [CrossRef]

43. Russell, M.H.; Berti, W.R.; Buck, R.C. Investigation of the Biodegradation Potential of a Fluoroacrylate Polymer Product in Aerobic Soils. Environ. Sci. Technol. 2008, 42, 800-807. [CrossRef]

44. Mak, Y.L.; Taniyasu, S.; Yeung, L.W.Y.; Lu, G.; Jin, L.; Yang, Y.; Lam, P.K.S.; Kannan, K.; Yamashita, N. Perfluorinated Compounds in Tap Water from China and Several Other Countries. Environ. Sci. Technol. 2009, 43, 4824-4829. [CrossRef]

45. Ghisi, R.; Manzetti, S. Accumulation of perfluorinated alkyl substances (PFAS) in agricultural plants: A review. Environ. Res. J. 2019, 169, 326-341. [CrossRef]

46. Bartolomé, M.; Gallego-picó, A.; Cutanda, F.; Huetos, O.; Esteban, M.; Pérez-Gómez, B.; Castaño, A. Perfluorinated alkyl substances in Spanish adults: Geographical distribution and determinants of exposure. Sci. Total Environ. 2017, 603-604, 352-360. [CrossRef]

47. Boiteux, V.; Dauchy, X.; Bach, C.; Colin, A.; Hemard, J.; Sagres, V.; Rosin, C.; Munoz, J. Science of the Total Environment Concentrations and patterns of perfluoroalkyl and polyfluoroalkyl substances in a river and three drinking water treatment plants near and far from a major production source. Sci. Total Environ. 2017, 583, 393-400. [CrossRef] [PubMed]

48. Loos, R.; Wollgast, J.; Huber, T. Polar herbicides, pharmaceutical products, perfluorooctanesulfonate (PFOS), perfluorooctanoate (PFOA), and nonylphenol and its carboxylates and ethoxylates in surface and tap waters around Lake Maggiore in Northern Italy. Anal. Bioanal. Chem. 2007, 387, 1469-1478. [CrossRef] [PubMed]

49. Lindstrom, A.B.; Strynar, M.J.; Libelo, E.L. Polyfluorinated compounds: Past, present, and future. Environ. Sci. Technol. 2011, 45, 7954-7961. [CrossRef] [PubMed]

50. Gellrich, V.; Brunn, H.; Stahl, T. Perfluoroalkyl and polyfluoroalkyl substances (PFASs) in mineral water and tap water. J. Environ. Sci. Health Part A Toxic/Hazard. Subst. Environ. Eng. 2013, 48, 129-135. [CrossRef] [PubMed]

51. Horst, J.; Mcdonough, J.; Ross, I.; Dickson, M.; Miles, J.; Hurst, J.; Storch, P. Advances in Remediation Solutions Water Treatment Technologies for PFAS: The Next Generation, Gr. Water Monit. Remediat. 2018, 38. [CrossRef]

52. Zhang, X.; Lohmann, R.; Dassuncao, C.; Hu, X.C.; Weber, A.K.; Vecitis, C.D.; Sunderland, E.M. Source Attribution of Poly- and Perfluoroalkyl Substances (PFASs) in Surface Waters from Rhode Island and the New York Metropolitan Area. Environ. Sci. Technol. Lett. 2016, 3, 316-321. [CrossRef]

53. Egeghy, P.P.; Judson, R.; Gangwal, S.; Mosher, S.; Smith, D.; Vail, J.; Cohen, E.A. The exposure data landscape for manufactured chemicals. Sci. Total Environ. 2012, 414, 159-166. [CrossRef]

54. Schultz, M.M.; Higgins, C.P.; Huset, C.A.; Luthy, R.G.; Barofsky, D.F.; Field, J.A. Fluorochemical mass flows in a municipal wastewater treatment facility. Environ. Sci. Technol. 2006, 40, 7350-7357. [CrossRef]

55. Yin, T.; Chen, H.; Reinhard, M.; Yi, X.; He, Y.; Gin, K.Y.H. Perfluoroalkyl and polyfluoroalkyl substances removal in a full-scale tropical constructed wetland system treating landfill leachate. Water Res. 2017, 125, 418-426. [CrossRef]

56. Bolan, N.; Sarkar, B.; Yan, Y.; Li, Q.; Wijesekara, H.; Kannan, K.; Tsang, D.C.W.; Schauerte, M.; Bosch, J.; Noll, H.; et al. Remediation of poly-and perfluoroalkyl substances (PFAS) contaminated soils-To mobilize or to immobilize or to degrade? J. Hazard. Mater. 2021, 401. [CrossRef]

57. Lee, H.; Tevlin, A.G.; Mabury, S.A.; Mabury, S.A. Fate of Polyfluoroalkyl Phosphate Diesters and Their Metabolites in Biosolids-Applied Soil: Biodegradation and Plant Uptake in Greenhouse and Field Experiments. Environ. Sci. Technol. 2014, 48. [CrossRef] [PubMed]

58. Karnjanapiboonwong, A.; Deb, S.K.; Subbiah, S.; Wang, D.; Anderson, T.A. Perfluoroalkylsulfonic and carboxylic acids in earthworms (Eisenia fetida): Accumulation and effects results from spiked soils at PFAS concentrations bracketing environmental relevance. Chemosphere 2018, 199, 168-173. [CrossRef] [PubMed]

59. Lechner, M.; Knapp, H. Carryover of Perfluorooctanoic Acid (PFOA) and Perfluorooctane Sulfonate (PFOS) from Soil to Plant and Distribution to the Different Plant Compartments Studied in Cultures of Carrots (Daucus carota ssp. Sativus), Potatoes (Solanum tuberosum), and cucumbers (Cucumis sativus). J. Agric. Food Chem. 2011, 11011-11088. [CrossRef] 
60. Stahl, T.; Heyn, J.; Thiele, H.; Hüther, J.; Failing, K.; Georgii, S.; Brunn, H. Carryover of Perfluorooctanoic Acid (PFOA) and Perfluorooctane Sulfonate (PFOS) from Soil to Plants. Arch. Environ. Contam. Toxicol. 2009, 57, 289-298. [CrossRef] [PubMed]

61. Cai, Y.; Chen, H.; Yuan, R.; Wang, F.; Chen, Z.; Zhou, B. Toxicity of perfluorinated compounds to soil microbial activity: Effect of carbon chain length, functional group and soil properties. Sci. Total Environ. 2019, 690, 1162-1169. [CrossRef] [PubMed]

62. Qiao, W.; Xie, Z.; Zhang, Y.; Liu, X.; Xie, S.; Huang, J.; Yu, L. Perfluoroalkyl substances (PFASs) influence the structure and function of soil bacterial community: Greenhouse experiment. Sci. Total Environ. 2018, 642, 1118-1126. [CrossRef]

63. Cai, Y.; Chen, H.; Yuan, R.; Wang, F.; Chen, Z.; Zhou, B. Metagenomic analysis of soil microbial community under PFOA and PFOS stress. Environ. Res. 2020, 188, 109838. [CrossRef]

64. Sun, Y.; Wang, T.; Peng, X.; Wang, P.; Lu, Y. Bacterial community compositions in sediment polluted by perfluoroalkyl acids (PFAAs) using Illumina high-throughput sequencing. Environ. Sci. Pollut. Res. 2016, 23, 10556-10565. [CrossRef]

65. Li, B.; Bao, Y.; Xu, Y.; Xie, S.; Huang, J. Vertical distribution of microbial communities in soils contaminated by chromium and perfluoroalkyl substances. Sci. Total Environ. 2017, 599-600, 156-164. [CrossRef]

66. Chen, H.; Wang, Q.; Cai, Y.; Yuan, R.; Wang, F.; Zhou, B.; Chen, Z. Effect of perfluorooctanoic acid on microbial activity in wheat soil under different fertilization conditions. Environ. Pollut. 2020, 264, 114784. [CrossRef]

67. Perkola, N.; Sainio, P. Survey of perfluorinated alkyl acids in Finnish effluents, storm water, landfill leachate and sludge. Environ. Sci. Pollut. Res. 2013, 20, 7979-7987. [CrossRef] [PubMed]

68. Busch, J.; Ahrens, L.; Sturm, R.; Ebinghaus, R. Polyfluoroalkyl compounds in landfill leachates. Environ. Pollut. 2010, 158, 1467-1471. [CrossRef] [PubMed]

69. Robey, N.M.; da Silva, B.F.; Annable, M.D.; Townsend, T.G.; Bowden, J.A. Concentrating Per- And Polyfluoroalkyl Substances (PFAS) in Municipal Solid Waste Landfill Leachate Using Foam Separation. Environ. Sci. Technol. 2020, 54, 12550-12559. [CrossRef] [PubMed]

70. Dauchy, X.; Boiteux, V.; Colin, A.; Hémard, J.; Bach, C.; Rosin, C.; Munoz, J.F. Deep seepage of per-and polyfluoroalkyl substances through the soil of a firefighter training site and subsequent groundwater contamination. Chemosphere 2019, 214, 729-737. [CrossRef]

71. Høisæter, Å.; Pfaff, A.; Breedveld, G.D. Leaching and transport of PFAS from aqueous film-forming foam (AFFF) in the unsaturated soil at a firefighting training facility under cold climatic conditions. J. Contam. Hydrol. 2019, 222, 112-122. [CrossRef]

72. Gao, Y.; Liang, Y.; Gao, K.; Wang, Y.; Wang, C.; Fu, J.; Wang, Y.; Jiang, G.; Jiang, Y. Levels, spatial distribution and isomer profiles of perfluoroalkyl acids in soil, groundwater and tap water around a manufactory in China. Chemosphere 2019, 227, 305-314. [CrossRef]

73. Wang, Y.; Fu, J.; Wang, T.; Liang, Y.; Pan, Y.; Cai, Y.; Jiang, G. Distribution of perfluorooctane sulfonate and other perfluorochemicals in the ambient environment around a manufacturing facility in china. Environ. Sci. Technol. 2010, 44, 8062-8067. [CrossRef]

74. Liu, B.; Zhang, H.; Yu, Y.; Xie, L.; Li, J.; Wang, X.; Dong, W. Perfluorinated Compounds (PFCs) in Soil of the Pearl River Delta, China: Spatial Distribution, Sources, and Ecological Risk Assessment. Arch. Environ. Contam. Toxicol. 2020, 78, 182-189. [CrossRef]

75. Chen, S.; Jiao, X.C.; Gai, N.; Li, X.J.; Wang, X.C.; Lu, G.H.; Piao, H.T.; Rao, Z.; Yang, Y.L. Perfluorinated compounds in soil, surface water, and groundwater from rural areas in eastern China. Environ. Pollut. 2016, 211, 124-131. [CrossRef]

76. Dalahmeh, S.; Tirgani, S.; Komakech, A.J.; Niwagaba, C.B.; Ahrens, L. Per-and polyfluoroalkyl substances (PFASs) in water, soil and plants in wetlands and agricultural areas in Kampala, Uganda. Sci. Total Environ. 2018, 631-632, 660-667. [CrossRef]

77. Armstrong, D.L.; Lozano, N.; Rice, C.P.; Ramirez, M.; Torrents, A. Temporal trends of perfluoroalkyl substances in limed biosolids from a large municipal water resource recovery facility. J. Environ. Manag. 2016, 165, 88-95. [CrossRef] [PubMed]

78. Herzke, D.; Olssonb, E.; Posner, S. Perfluoroalkyl and polyfluoroalkyl substances (PFASs) in consumer products in Norway-A pilot study. Chemosphere 2012, 88, 980-987. [CrossRef] [PubMed]

79. Clarke, B.O.; Anumol, T.; Barlaz, M.; Snyder, S.A. Investigating landfill leachate as a source of trace organic pollutants. Chemosphere 2015, 127, 269-275. [CrossRef] [PubMed] 
80. Benskin, J.P.; Li, B.; Ikonomou, M.G.; Grace, J.R.; Li, L.Y. Per-and Polyfl uoroalkyl Substances in Landfill Leachate: Patterns, Time Trends, and Sources. Environ. Sci. Technol. 2012, 46, 11532-11540. [CrossRef]

81. Eggen, T.; Moeder, M.; Arukwe, A. Municipal landfill leachates: A signifi cant source for new and emerging pollutants. Sci. Total Environ. 2010, 408, 5147-5157. [CrossRef]

82. Fuertes, I.; Gómez-Lavín, S.; Elizalde, M.P.; Urtiaga, A. Perfluorinated alkyl substances (PFASs) in northern Spain municipal solid waste landfill leachates. Chemosphere 2017, 168, 399-407. [CrossRef]

83. Huset, C.A.; Barlaz, M.A.; Barofsky, D.F.; Field, J.A. Quantitative determination of fluorochemicals in municipal landfill leachates. Chemosphere 2011, 82, 1380-1386. [CrossRef]

84. Garg, S.; Kumar, P.; Mishra, V.; Guijt, R.; Singh, P.; Dumée, L.F.; Sharma, R.S. A review on the sources, occurrence and health risks of per-/poly-fluoroalkyl substances (PFAS) arising from the manufacture and disposal of electric and electronic products. J. Water Process Eng. 2020, 38, 101683. [CrossRef]

85. Loos, R.; Carvalho, R.; Anto, D.C.; Locoro, G.; Tavazzi, S.; Paracchini, B.; Ghiani, M.; Lettieri, T.; Blaha, L.; Jarosova, B.; et al. EU-wide monitoring survey on emerging polar organic contaminants in wastewater treatment plant effluents. Water Res. 2013, 7, 6475-6487. [CrossRef]

86. Zhang, Q.; Zhang, W.L.; Liang, Y.N. Adsorption of perfluoroalkyl and polyfluoroalkyl substances (PFASs) from aqueous solution-A review. Sci. Total Sci. Total Environ. 2020, 748, 142354. [CrossRef]

87. Xiao, F. Emerging poly-and perfluoroalkyl substances in the aquatic environment: A review of current literature. Water Res. 2017, 124, 482-495. [CrossRef] [PubMed]

88. Ochoa-Herrera, V.; Sierra-Alvarez, R. Removal of perfluorinated surfactants by sorption onto granular activated carbon, zeolite and sludge. Chemosphere 2008, 72, 1588-1593. [CrossRef]

89. Tang, H.; Xiang, Q.; Lei, M.; Yan, J.; Zhu, L.; Zou, J. Efficient degradation of perfluorooctanoic acid by UV-Fenton process. Chem. Eng. J. 2012, 184, 156-162. [CrossRef]

90. Gorenflo, A.; Veliizquez-Padon, D.; Frimmel, F.H. Nanofiltration of a German groundwater of high hardness and NOM content: Performance and costs. Desalination 2002, 151, 253-265. [CrossRef]

91. Hori, H.; Yamamoto, A.R.I. Efficient Decomposition of Environmentally Persistent Perfluorocarboxylic Acids by Use of Persulfate as a Photochemical Oxidant. Environ. Sci. Technol. 2005, 39, 2383-2388. [CrossRef] [PubMed]

92. Vecitis, C.D.; Wang, Y.; Cheng, J.I.E.; Park, H.; Mader, B.T. Sonochemical Degradation of Perfluorooctanesulfonate in Aqueous Film-Forming Foams. Environ. Sci. Technol. 2010, 44, 432-438. [CrossRef]

93. Franke, V.; McCleaf, P.; Lindegren, K.; Ahrens, L. Efficient removal of per-And polyfluoroalkyl substances (PFASs) in drinking water treatment: Nanofiltration combined with active carbon or anion exchange. Environ. Sci. Water Res. Technol. 2019, 5, 1836-1843. [CrossRef]

94. Zhang, D.; Luo, Q.; Gao, B.; Chiang, S.D.; Woodward, D.; Huang, Q. Sorption of perfluorooctanoic acid, perfluorooctane sulfonate and perfluoroheptanoic acid on granular activated carbon. Chemosphere 2016, 144, 2336-2342. [CrossRef]

95. Li, J.; Li, Q.; Li, L.; Xu, L. Removal of perfluorooctanoic acid from water with economical mesoporous melamine-formaldehyde resin microsphere. Chem. Eng. J. 2017, 320, 501-509. [CrossRef]

96. Du, Z.; Deng, S.; Chen, Y.; Wang, B.; Huang, J.; Wang, Y.; Yu, G. Removal of perfluorinated carboxylates from washing wastewater of perfluorooctanesulfonyl fluoride using activated carbons and resins. J. Hazard. Mater. 2015, 286, 136-143. [CrossRef]

97. Gao, Y.; Deng, S.; Du, Z.; Liu, K.; Yu, G. Adsorptive removal of emerging polyfluoroalky substances F-53B and PFOS by anion-exchange resin: A comparative study. J. Hazard. Mater. 2017, 323, 550-557. [CrossRef] [PubMed]

98. Franke, V.; Schäfers, D.; Lindberg, J.J.; Ahrens, L. Removal of per-and polyfluoroalkyl substances (PFASs) from tap water using heterogeneously catalyzed ozonation. Environ. Sci. Water Res. Technol. 2019, 5, 1887-1896. [CrossRef]

99. Andres, V.; Espana, A.; Mallavarapu, M.; Naidu, R. Treatment technologies for aqueous perfluorooctanesulfonate (PFOS) and perfluorooctanoate (PFOA): A critical review with an emphasis on field testing. Environ. Technol. Innov. 2015, 4, 168-181. [CrossRef]

100. Collings, A.F.; Gwan, P.B. Large scale environmental applications of high power ultrasound. Ultrason. Sonochem. 2010, 17, 1049-1053. [CrossRef] [PubMed]

101. Fernandez, N.A.; Rodriguez-Freire, L.; Keswani, M.; Sierra-Alvarez, R. Effect of chemical structure on the sonochemical degradation of perfluoroalkyl and polyfluoroalkyl substances (PFASs) ${ }^{\dagger}$. Environ. Sci. Water Res. Technol. 2016, 975-983. [CrossRef] 
102. Zhao, L.; Bian, J.; Zhang, Y.; Zhu, L.; Liu, Z. Comparison of the sorption behaviors and mechanisms of perfluorosulfonates and perfluorocarboxylic acids on three kinds of clay minerals. Chemosphere 2014, 114, 51-58. [CrossRef]

103. Zhang, R.; Yan, W.; Jing, C. Mechanistic study of PFOS adsorption on kaolinite and montmorillonite, Colloids Surfaces A Physicochem. Eng. Asp. 2014, 462, 252-258. [CrossRef]

104. Wu, T.; Wu, Z.; Ma, D.; Xiang, W.; Zhang, J.; Liu, H.; Deng, Y.; Tan, S.; Cai, X. Fabrication of Few-Layered Porous Graphite for Removing Fluorosurfactant from Aqueous Solution. Langmuir 2018, 34, 15181-15188. [CrossRef]

105. Chen, X.; Xia, X.; Wang, X.; Qiao, J.; Chen, H. A comparative study on sorption of perfluorooctane sulfonate (PFOS) by chars, ash and carbon nanotubes. Chemosphere 2011, 83, 1313-1319. [CrossRef]

106. Zhang, Q.; Deng, S.; Yu, G.; Huang, J. Removal of perfluorooctane sulfonate from aqueous solution by crosslinked chitosan beads: Sorption kinetics and uptake mechanism. Bioresour. Technol. 2011, 102, 2265-2271. [CrossRef]

107. Fagbayigbo, B.O.; Opeolu, B.O.; Fatoki, O.S. Adsorption of perfluorooctanoic acid (PFOA) and perfluorooctane sulfonate (PFOS) from water using leaf biomass (Vitis vinifera) in a fixed-bed column study. J. Environ. Health Sci. Eng. 2020, 18, 221-233. [CrossRef] [PubMed]

108. Stebel, E.K.; Pike, K.A.; Nguyen, H.; Hartmann, H.A.; Klonowski, M.J.; Lawrence, M.G.; Collins, R.M.; Hefner, C.E.; Edmiston, P.L. Absorption of short-chain to long-chain perfluoroalkyl substances using swellable organically modified silica. Environ. Sci. Water Res. Technol. 2019, 5, 1854-1866. [CrossRef]

109. Qian, J.; Shen, M.; Wang, P.; Wang, C.; Hu, J.; Hou, J.; Ao, Y.; Zheng, H.; Li, K.; Liu, J. Co-adsorption of perfluorooctane sulfonate and phosphate on boehmite: Influence of temperature, phosphate initial concentration and pH. Ecotoxicol. Environ. Saf. 2017, 137, 71-77. [CrossRef] [PubMed]

110. Jian, J.M.; Zhang, C.; Wang, F.; Lu, X.W.; Wang, F.; Zeng, E.Y. Effect of solution chemistry and aggregation on adsorption of perfluorooctanesulphonate (PFOS) to nano-sized alumina. Environ. Pollut. 2019, 251, 425-433. [CrossRef] [PubMed]

111. Sunderland, E.M.; Hu, X.C.; Dassuncao, C.; Tokranov, A.K.; Wagner, C.C.; Allen, J.G. A review of the pathways of human exposure to poly-and perfluoroalkyl substances (PFASs) and present understanding of health effects. J. Expo. Sci. Environ. Epidemiol. 2019, 29, 131-147. [CrossRef] [PubMed]

112. Gebbink, W.A.; Berger, U.; Cousins, I.T. Estimating human exposure to PFOS isomers and PFCA homologues: The relative importance of direct and indirect (precursor) exposure Estimating human exposure to PFOS isomers and PFCA homologues: The relative importance of direct and indirect (precursor). Environ. Int. 2015, 74, 160-169. [CrossRef] [PubMed]

113. Skaar, J.S.; Ræder, E.M.; Lyche, J.L.; Ahrens, L.; Kallenborn, R. Elucidation of contamination sources for poly-and perfluoroalkyl substances (PFASs) on Svalbard (Norwegian Arctic). Environ. Sci. Pollut. Res. 2019, 26, 7356-7363. [CrossRef]

114. Andersen, M.E.; Butenhoff, J.L.; Chang, S.; Farrar, D.G.; Kennedy, G.L.; Lau, C.; Olsen, G.W.; Seed, J.; Wallace, K.B. Perfluoroalkyl Acids and Related Chemistries-Toxicokinetics and Modes of Action. Toxicol. Sci. 2008, 102, 3-14. [CrossRef]

115. Hoffman, K.; Webster, T.F.; Bartell, S.M.; Weisskopf, M.G.; Fletcher, T. Private Drinking Water Wells as a Source of Exposure to Perfluorooctanoic Acid Private Drinking Water Wells as a Source of Exposure to Perfluorooctanoic Acid (PFOA) in Communities Surrounding a Fluoropolymer Production Facility. Environ. Health Perspect. 2010, 119, 92-97. [CrossRef]

116. Longpré, D.; Lorusso, L.; Levicki, C.; Carrier, R.; Cureton, P. PFOS, PFOA, LC-PFCAS, and certain other PFAS: A focus on Canadian guidelines and guidance for contaminated sites management. Environ. Technol. Innov. 2020, 18, 100752. [CrossRef]

117. Seyoum, A.; Pradhan, A.; Jass, J.; Olsson, P. Perfluorinated alkyl substances impede growth, reproduction, lipid metabolism and lifespan in Daphnia magna. Sci. Total Environ. 2020, 737, 139682. [CrossRef] [PubMed]

118. Skogheim, T.S.; Villanger, G.D.; Weyde, K.V.F.; Engel, S.M.; Surén, P.; Øie, M.G.; Skogan, A.H.; Biele, G.; Zeiner, P.; Øvergaard, K.R.; et al. Prenatal exposure to perfluoroalkyl substances and associations with symptoms of attention-deficit/hyperactivity disorder and cognitive functions in preschool children. Int. J. Hyg. Environ. Health 2020, 223, 80-92. [CrossRef] [PubMed] 
119. Niu, J.; Liang, H.; Tian, Y.; Yuan, W.; Xiao, H.; Hu, H.; Sun, X.; Song, X.; Wen, S.; Yang, L.; et al. Prenatal plasma concentrations of Perfluoroalkyl and polyfluoroalkyl substances and neuropsychological development in children at four years of age. Environ. Health 2019, 18, 53. [CrossRef] [PubMed]

120. McCarthy, C.; Kappleman, W.; DiGuiseppi, W. Ecological Considerations of Per-and Polyfluoroalkyl Substances (PFAS). Curr. Pollut. Reports. 2017, 3, 289-301. [CrossRef]

121. Cordner, A.; College, W.; Ave, B.; Walla, W.; States, U.; Richter, L.; Brown, P. Can Chemical Class Approaches Replace Chemical-by-Chemical Strategies? Lessons from Recent U.S. FDA Regulatory Action on per-and Polyfluoroalkyl Substances. Environ. Sci. Technol. 2016, 50, 12584-12591. [CrossRef] [PubMed]

122. Australian-Government. Health Based Guidance Values for PFAS; Australian-Government, Department of Health: Canberra, Australia, 2019.

Publisher's Note: MDPI stays neutral with regard to jurisdictional claims in published maps and institutional affiliations.

(C) 2020 by the authors. Licensee MDPI, Basel, Switzerland. This article is an open access article distributed under the terms and conditions of the Creative Commons Attribution (CC BY) license (http://creativecommons.org/licenses/by/4.0/). 